\title{
PRESSURIZED FLUIDIZED BED COMBUSTION SECOND-GENERATION SYSTEM RESEARCH AND DEVELOPMENT
}

TECHNICAL PROGRESS REPORT FOR PHASE 3

OCTOBER 1, 2001 THROUGH SEPTEMBER 2002

By
A. Robertson
Foster Wheeler Development Corporation
D. Horazak
Siemens Westinghouse Power Corporation
R. Newby
Siemens Westinghouse Power Corporation
H. Goldstein
Parsons Infrastructure and Technology Group, Inc.

November 2002

Work Performed Under Contract: DE-AC21-86MC21023

For

U.S. Department of Energy

Office of Fossil Energy

National Energy Technology Laboratory

Morgantown, West Virginia

By

Foster Wheeler Development Corporation

Livingston, New Jersey 


\section{$\underline{\text { Disclaimer }}$}

"This report was prepared as an account of work sponsored by an agency of the United States Government. Neither the United States Government nor any agency thereof, nor any of their employees, makes any warranty, express or implied, or assumes any legal liability or responsibility for the accuracy, completeness, or usefulness of any information, apparatus, product, or process disclosed, or represents that its use would not infringe upon privately owned rights. Reference herein to any specific commercial product, process, or service by trade name, trademark, manufacturer, or otherwise does not necessarily constitute or imply its endorsement by the United States Government or any agency thereof. The views and opinions of authors expressed herein do not necessarily state or reflect those of the United States Government or any agency thereof." 


\section{TECHNICAL PROGRESS REPORT NUMBER 21023R303 FOR OCTOBER 2001 THROUGH SEPTEMBER 2002}

\section{Abstract}

Research is being conducted under United States Department of Energy (DOE) Contract DE-AC21-86MC21023 to develop a new type of coal-fired plant for electric power generation. This new type of plant - called a Second-Generation or Advanced Pressurized Circulating Fluidized Bed Combustion (APCFB) plant - offers the promise of efficiencies greater than $45 \%(\mathrm{HHV})$, with both emissions and a cost of electricity that are significantly lower than conventional pulverized-coal-fired plants with scrubbers.

The APCFB plant incorporates the partial gasification of coal in a carbonizer, the combustion of carbonizer char in a pressurized circulating fluidized bed boiler (PCFB), and the combustion of carbonizer syngas in a topping combustor to achieve gas turbine inlet temperatures of $2300 \mathrm{EF}$ and higher.

A conceptual design was previously prepared for this new type of plant and an economic analysis presented, all based on the use of a Siemens Westinghouse W501F gas turbine with projected carbonizer, PCFB, and topping combustor performance data. Having tested these components at the pilot plant stage, the referenced conceptual design is being updated to reflect more accurate performance predictions together with the use of the more advanced Siemens Westinghouse W501G gas turbine and a conventional $2400 \mathrm{psig} / 1050 \mathrm{EF} / 1050 \mathrm{EF} / 2-1 / 2 \mathrm{in}$. steam turbine. This report describes the updated plant which is projected to have an HHV efficiency of $48 \%$ and identifies work completed for the October 2001 through September 2002 time period. 


\section{$\underline{\text { Table of Contents }}$}

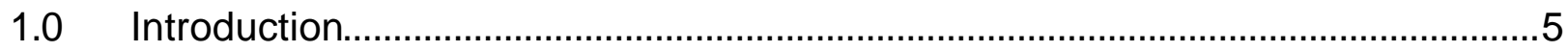

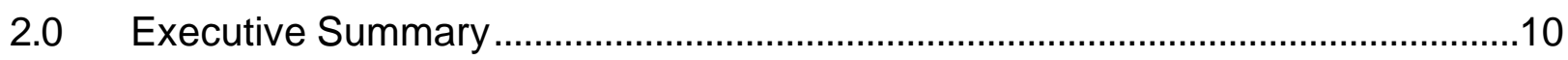



4.0 Results and Discussion (Plant Conceptual Design) ………..............................11

4.1 Heat and Material Balances …………….............................................11

4.2 Process Flow Design .........................................................................15

$4.3 \quad$ Coal-Sorbent Feed Systems ………………...................................19

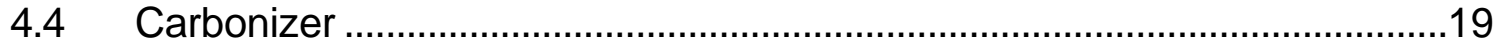

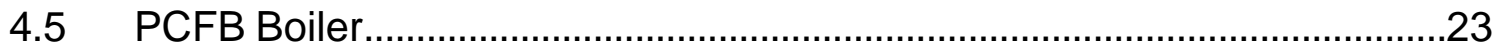

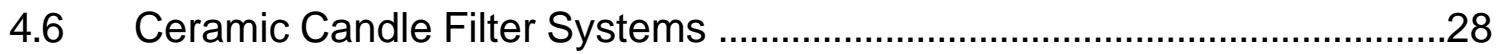

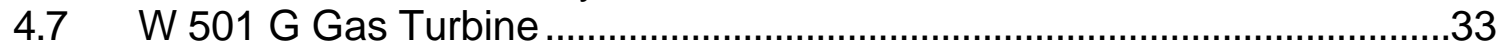

4.8 Plant Control System Design Basis..........................................................36

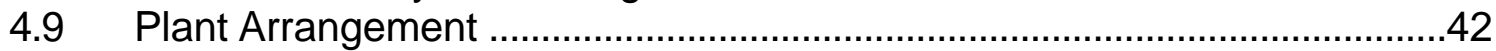

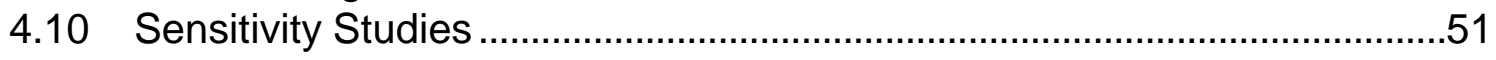

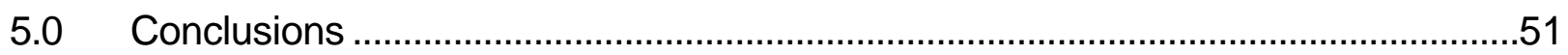

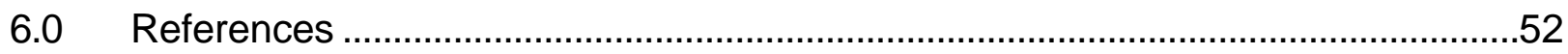

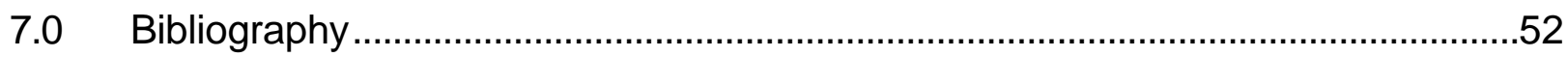

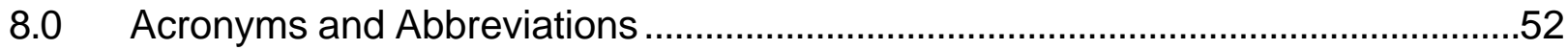




\section{List of Graphical Materials}

\section{Figures}

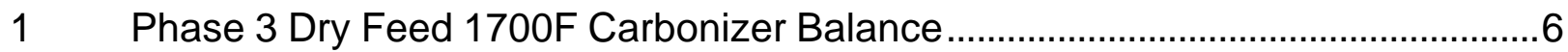

23 Boiler BFW-Steam Circuitry Arrangement ………..........................................

32 Boiler BFW-Steam Circuitry Arrangement ….................................................. 8

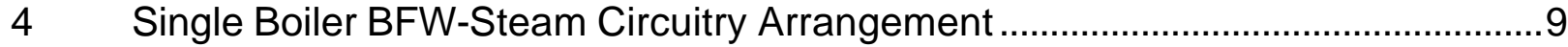

$5 \quad$ Boiler Feed Water Circuitry Arrangement .......................................................12

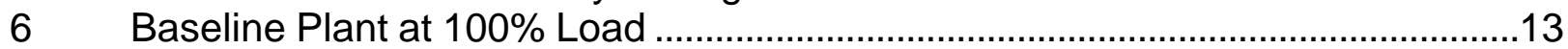

$7 \quad$ Baseline Plant at 50\% Load .........................................................................14

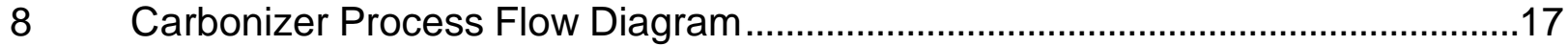

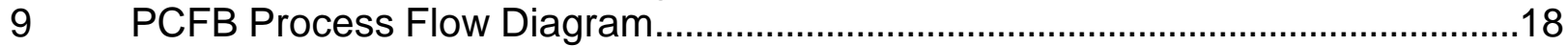

10 Lock Hopper Feed Systems ………………..................................................21

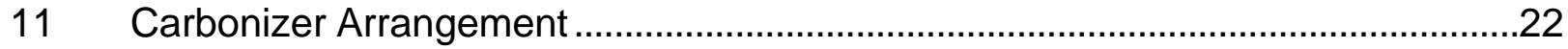

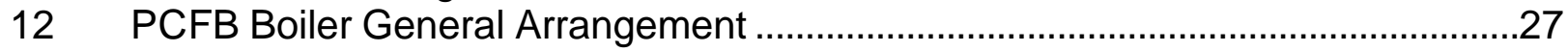

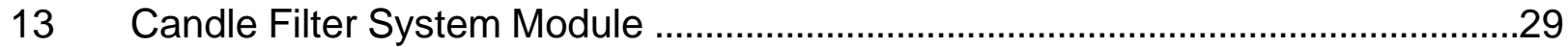

$14 \quad$ Hot Gas Filter Maintenance Features .............................................................29

15 Carbonizer Filter Vessel and Pulse Control Skid ..............................................31

$16 \quad$ PCFB Filter Vessel and Pulse Control Skid ......................................................32

17 Syngas Combustor Flow Arrangement ............................................................34

18 Plan View of Gas Turbine Installation ..............................................................35

19 Syngas Combustor Manifold Connections ……..................................................36

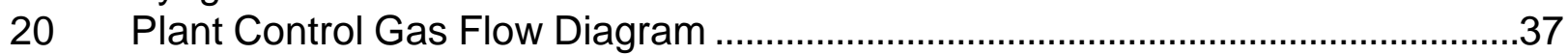

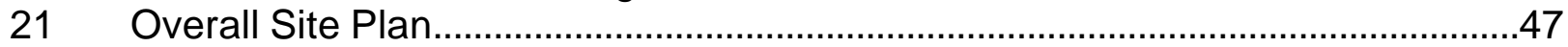

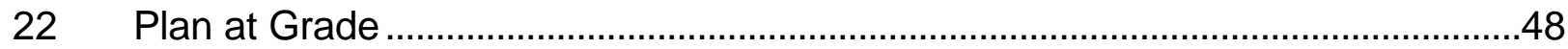

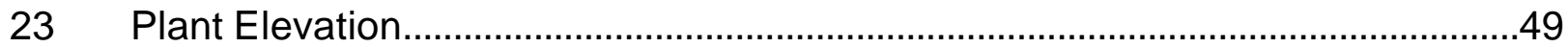

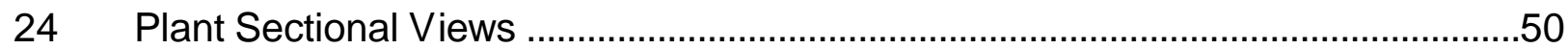

$25 \quad$ Baseline Plant with Limestone Sorbent ..........................................................53

$26 \quad$ Baseline Plant with Alloy Filter/Piping ..............................................................54

\section{Tables}

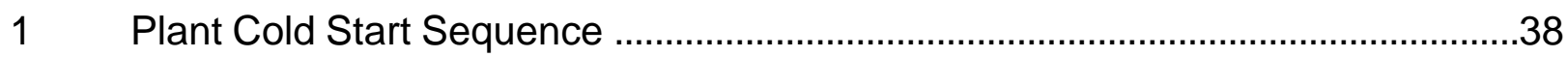

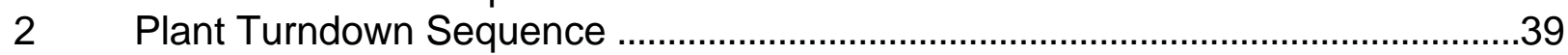

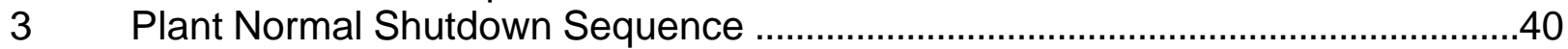

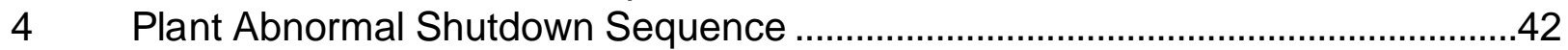




\section{$1.0 \quad$ Introduction}

The Second-Generation PFB Combustion Plant conceptual design prepared in Phase I [6-1] is being updated to reflect the benefit of pilot plant test data and the latest advances in gas turbine technology. The updated plant is being designed to operate with 95 percent sulfur capture and a single Siemens Westinghouse (SW) 501G gas turbine. Using carbonizer and gas turbine data generated by Foster Wheeler (FW) and SW respectively, Parsons Infrastructure \& Technology prepared preliminary plant heat and material balances for evaluations. These preliminary balances indicated:

1. dry feed would yield a plant efficiency approximately 4 percentage points higher than paste feed,

2. a 1700E carbonizer temperature (see Fig. 1 for the predicted carbonizer performance) yielded a higher efficiency than an 1800EF temperature.

The $501 \mathrm{G}$ gas turbine has an air compressor discharge temperature of $811 \mathrm{EF}$ and an exhaust temperature of $1140 \mathrm{EF}$. Both of these streams represent high sources of heat and must be cooled, the air to 600EF to be compatible with a 700EF PCFB pressure vessel design temperature and the exhaust for a 275EF stack gas temperature. Because of their relatively high temperature, they can be used for feed water heating, steam generation and/or steam superheating and reheating. As a result, the plant could have one boiler (the PCFB boiler), or as many as three boilers if the cooling of the above streams is used to generate steam. Three different plant arrangements using one, two and then three boilers were considered; the three-boiler arrangement was found to minimize the feedwater flow/steam turbine size and maximize the plant efficiency. After reviewing the three arrangements shown in Figs. 2, 3 and 4, it was felt the operating complexity associated with a three-boiler plant did not justify the $1 / 2$ point increase in plant efficiency it provided, and it was eliminated. 


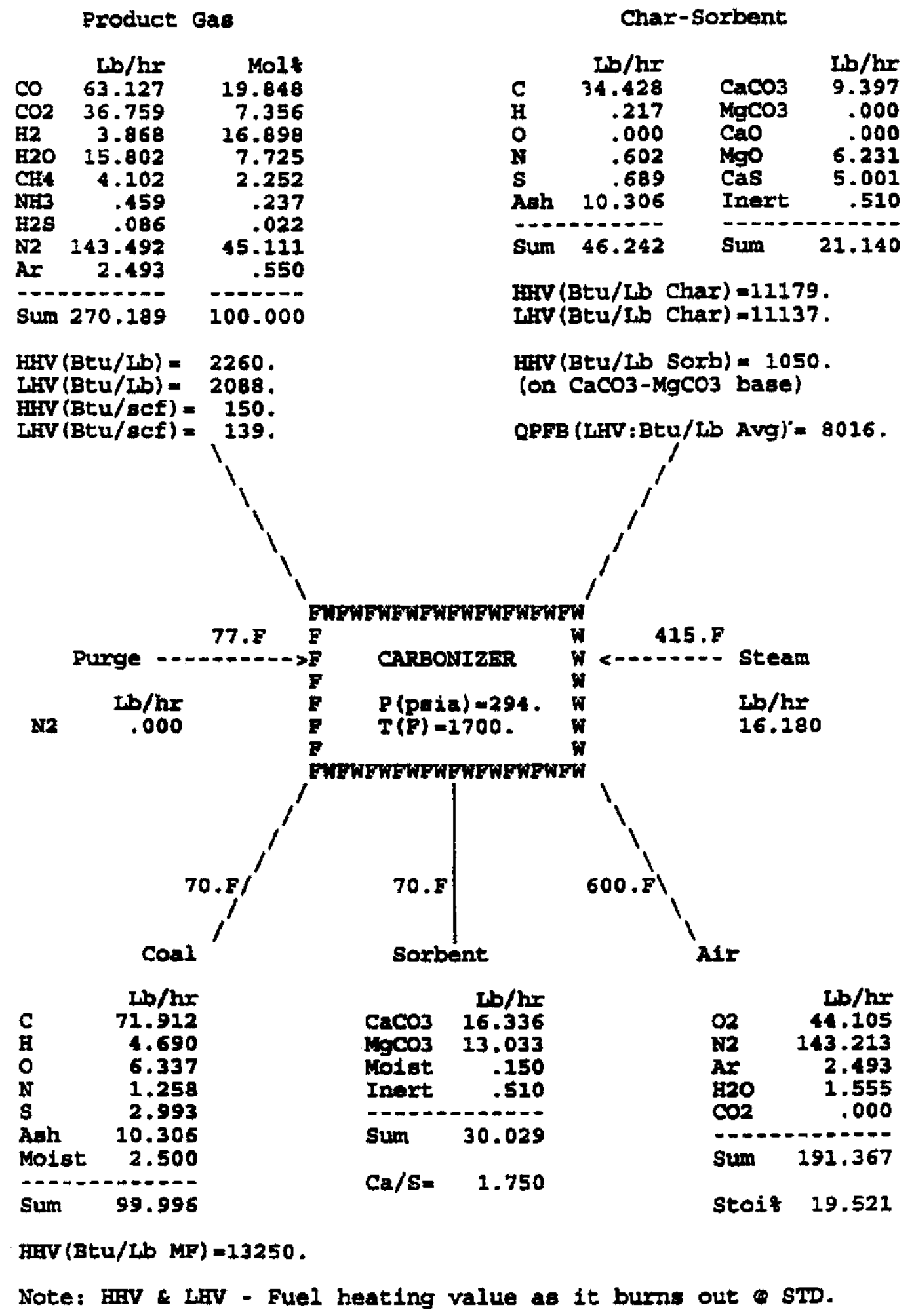

Fig. 1 Phase 3 Dry Feed 1700EF Carbonizer Balance 6/4/98 


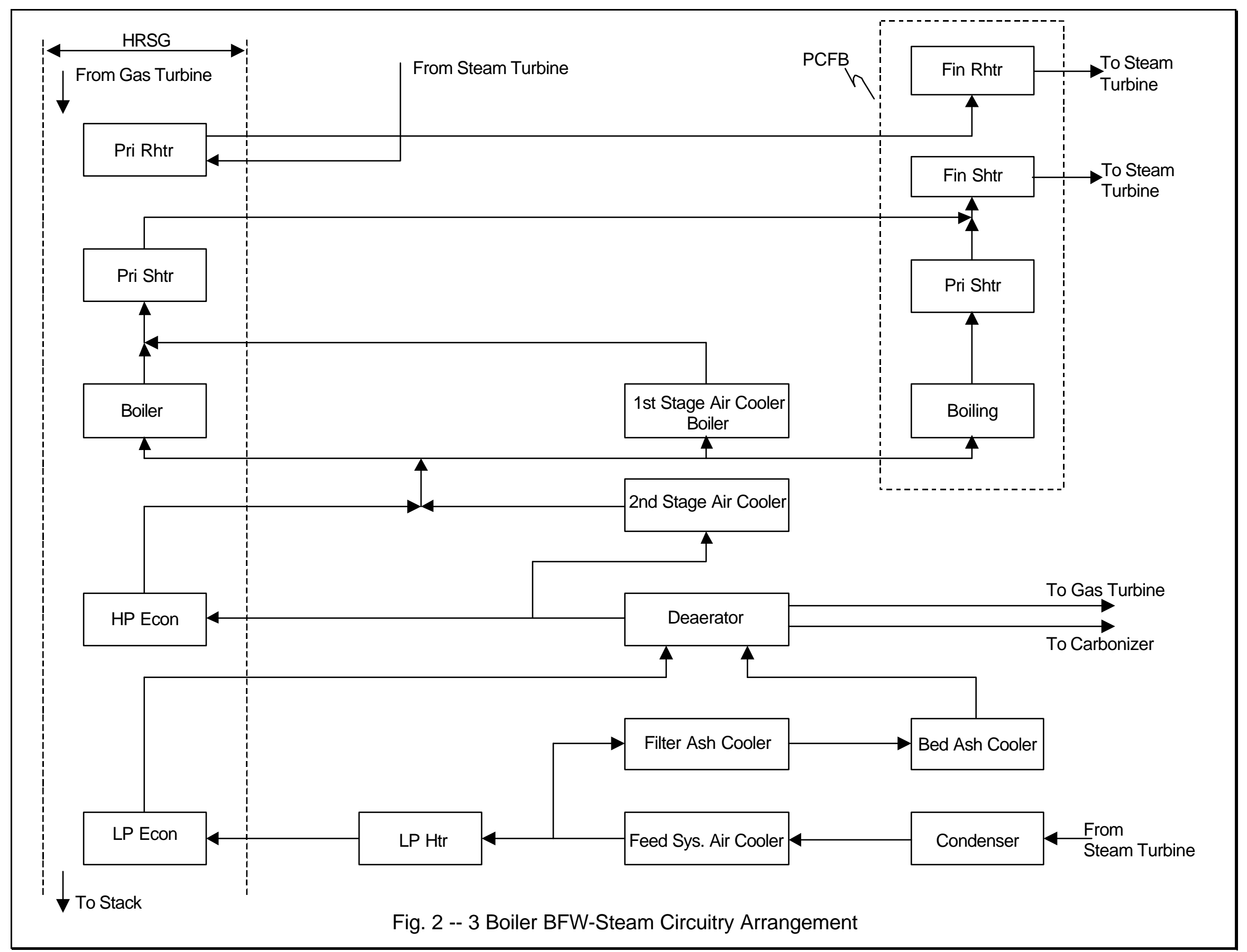




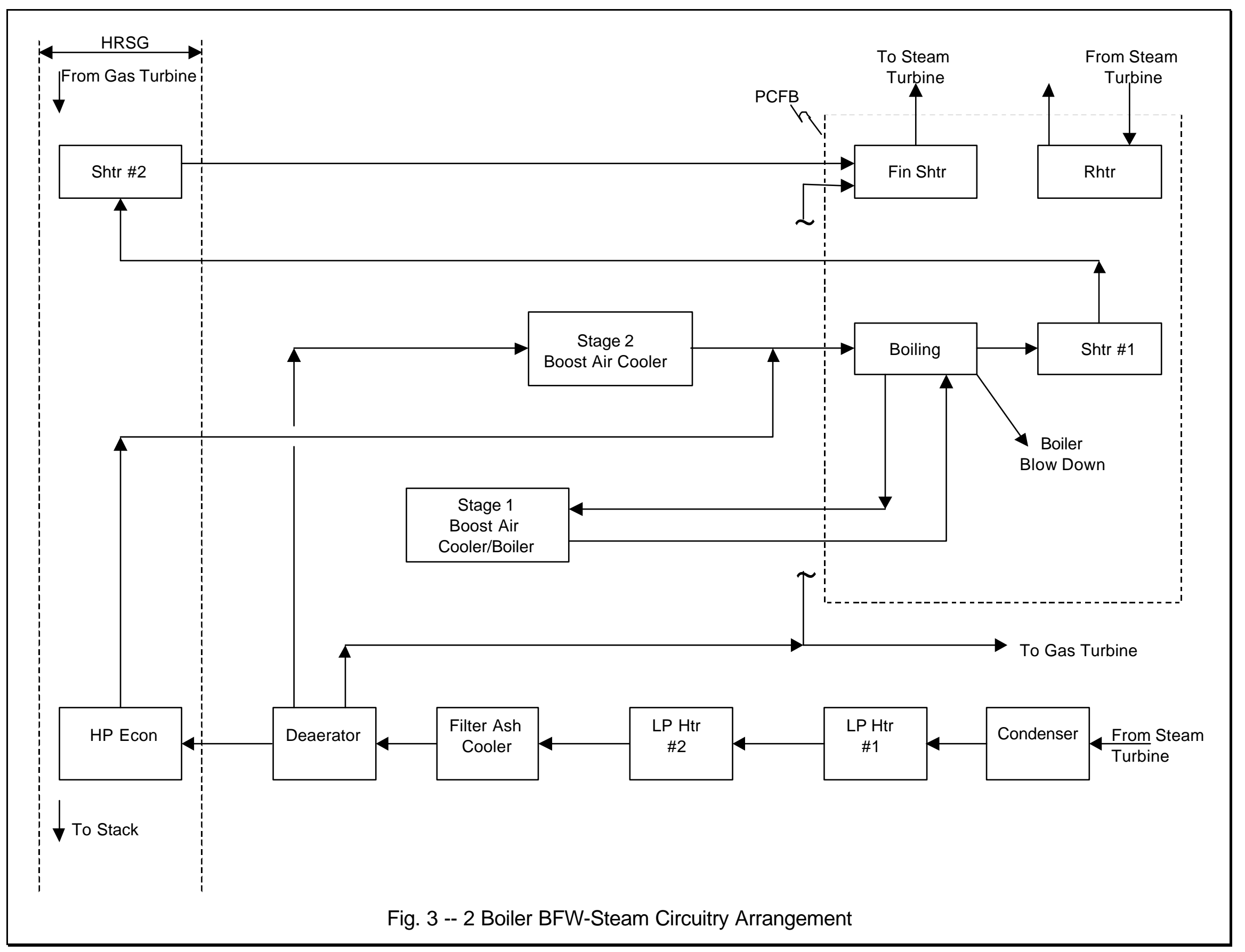




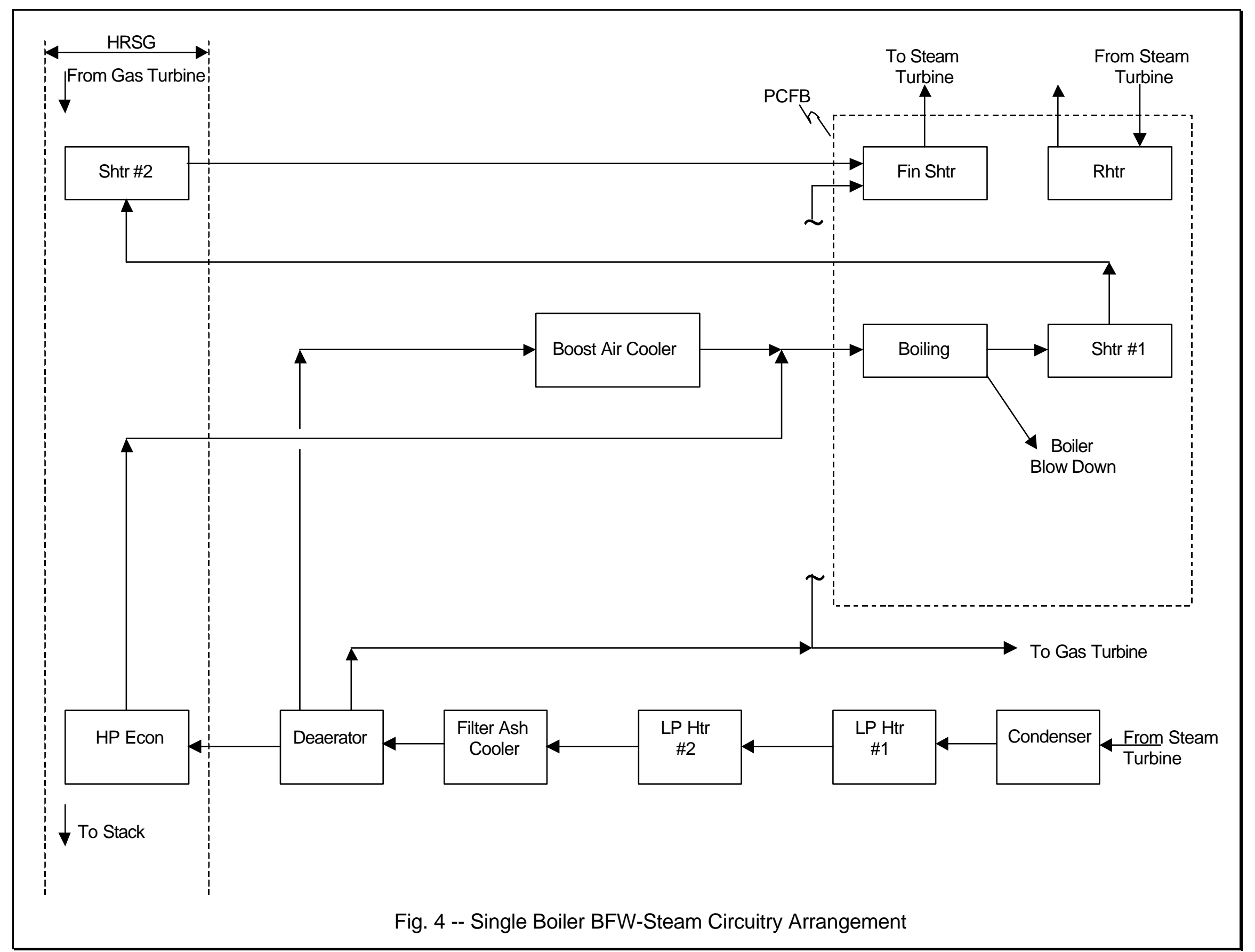


The performance projected for the single and two-boiler plant configurations were:

Gross Power, MWe

Gas Turbine

Steam Turbine

Total

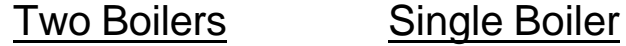

239.25

267.46

506.71

24.89

481.82

47.5

7184
239.25

299.30

538.55
47.0

26.20

512.35

7251

Net Power, MWe

Plant HHV Efficiency, \%

Plant HHV Heat Rate, Btu/kwhr

The above results were discussed with the DOE, and it was decided to proceed with the two-boiler arrangement because of its potential for half a point higher efficiency at a modest increase in complexity.

\subsection{Executive Summary}

Under DOE DE-AC21-86MC21023 Foster Wheeler is leading a team of companies in conducting research and development of electricity producing, coal fired secondgeneration PCFB combustion plants. The project is divided into three phases. In Phase 1 the second-generation PCFB plant was conceptually designed, its economics determined, and plans formulated for pilot plant testing its key components in Phase 2. The Phase 2 separate testing of key components was successful and in Phase 3 several of the key components were tested as an integrated subsystem. Having completed testing, the conceptual plant design prepared in Phase 1 is being updated to reflect those test results together with the use of today's commercially available gas turbines and steam turbines, e.g., a Siemens Westinghouse W 501G gas turbine and a $2400 \mathrm{psig} / 1050 \mathrm{EF} / 1050 \mathrm{EF} / 2-1 / 2$ " Hg steam turbine.

The update of the plant conceptual design has been completed and an HHV efficiency of 48 percent is projected. Plant costs are being determined and a sensitivity study is underway to determine the effects of different operating conditions and design assumptions on plant performance and economics. This report describes the plant and reports on work completed during this reporting period.

\subsection{Experimental}

Not applicable. The commercial plant conceptual design effort does not involve experimental testing. 


\subsection{Results and Discussion}

The conceptual design of the updated Second Generation PFB plant, called the baseline plant, continued to completion. Equipment lists and equipment weights were finalized, component costs were estimated, and Parsons began to determine total plant cost and economics. The finalized baseline plant configuration is described in the following section.

\subsection{Heat and Material Balance}

Parsons modified the Fig. 3 two-boiler plant circuitry arrangement to allow recovery of heat contained in the PCFB bottom ash drain and the transport air cooler; Fig. 5 reflects these improvements. Based on the new configuration, Parsons prepared the full-load and $50 \%$ load heat and material balance shown in Figs. 6 and 7 for the plant. Approximately $55 \%$ of the gas turbine air compressor discharge is exported for use in the carbonizer and PCFB legs of the plant. To compensate for the pressure drop induced by their components, a boost compressor raises the air pressure by 40 psi. A second and much smaller boost compressor provides a source of high-pressure air for loop seals, the transport of coal-sorbent into the units, etc. A portion of the gas exhausting from the gas turbine is used to dry the coal before it enters the plant feed systems. 


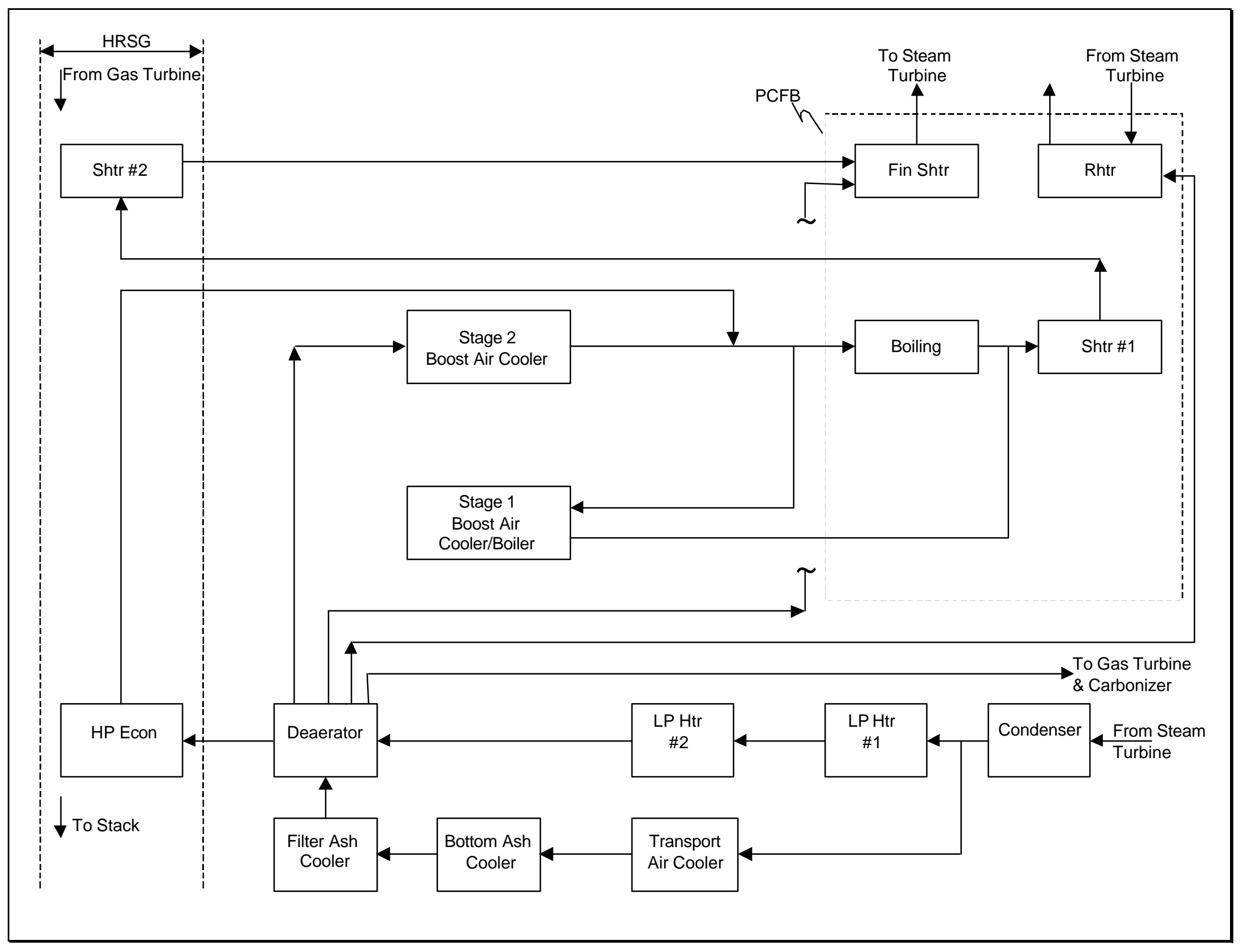

Fig. 5 Boiler Feed Water Circuitry Arrangement 


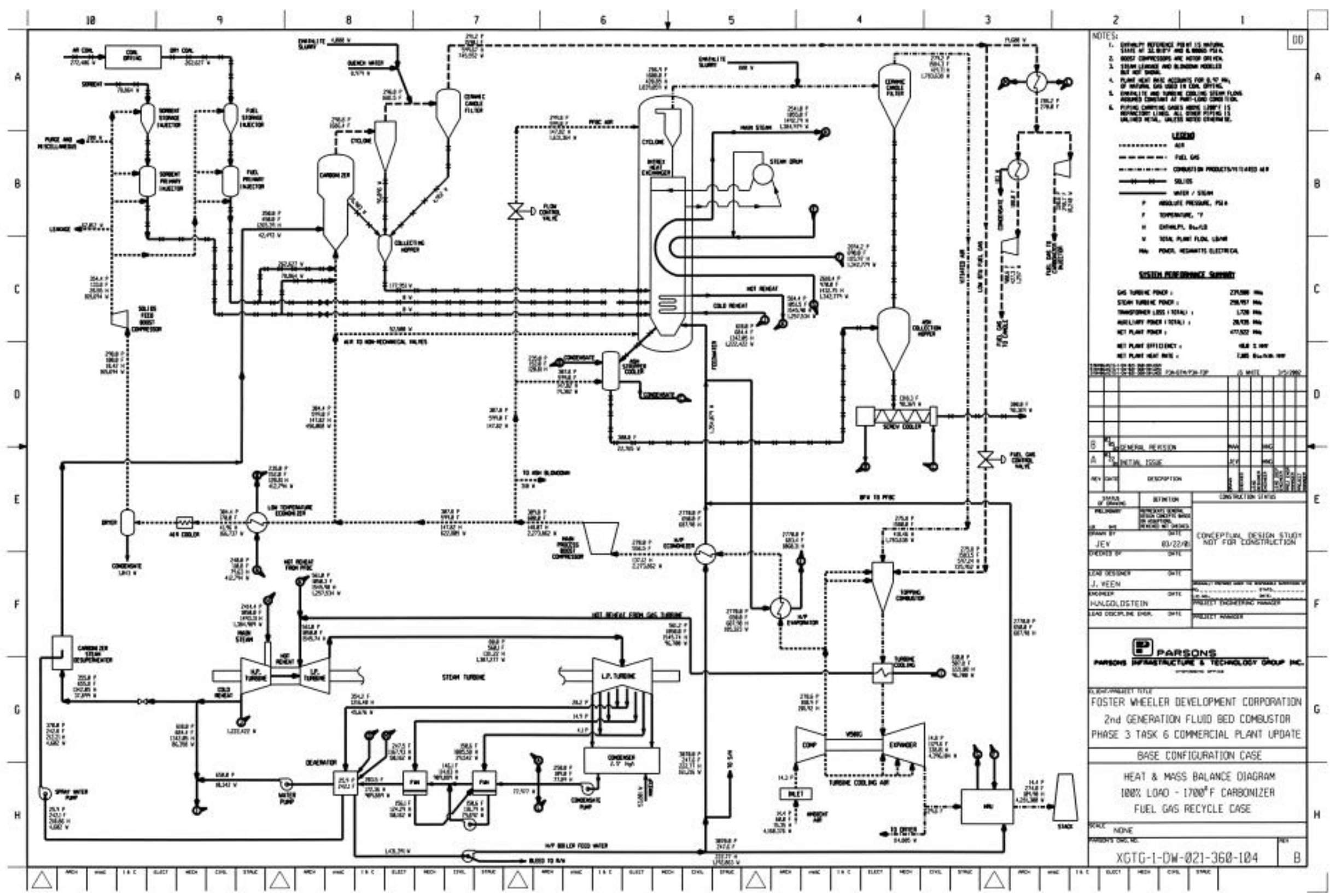

Fig. 6 Baseline Plant at 100\% Load 


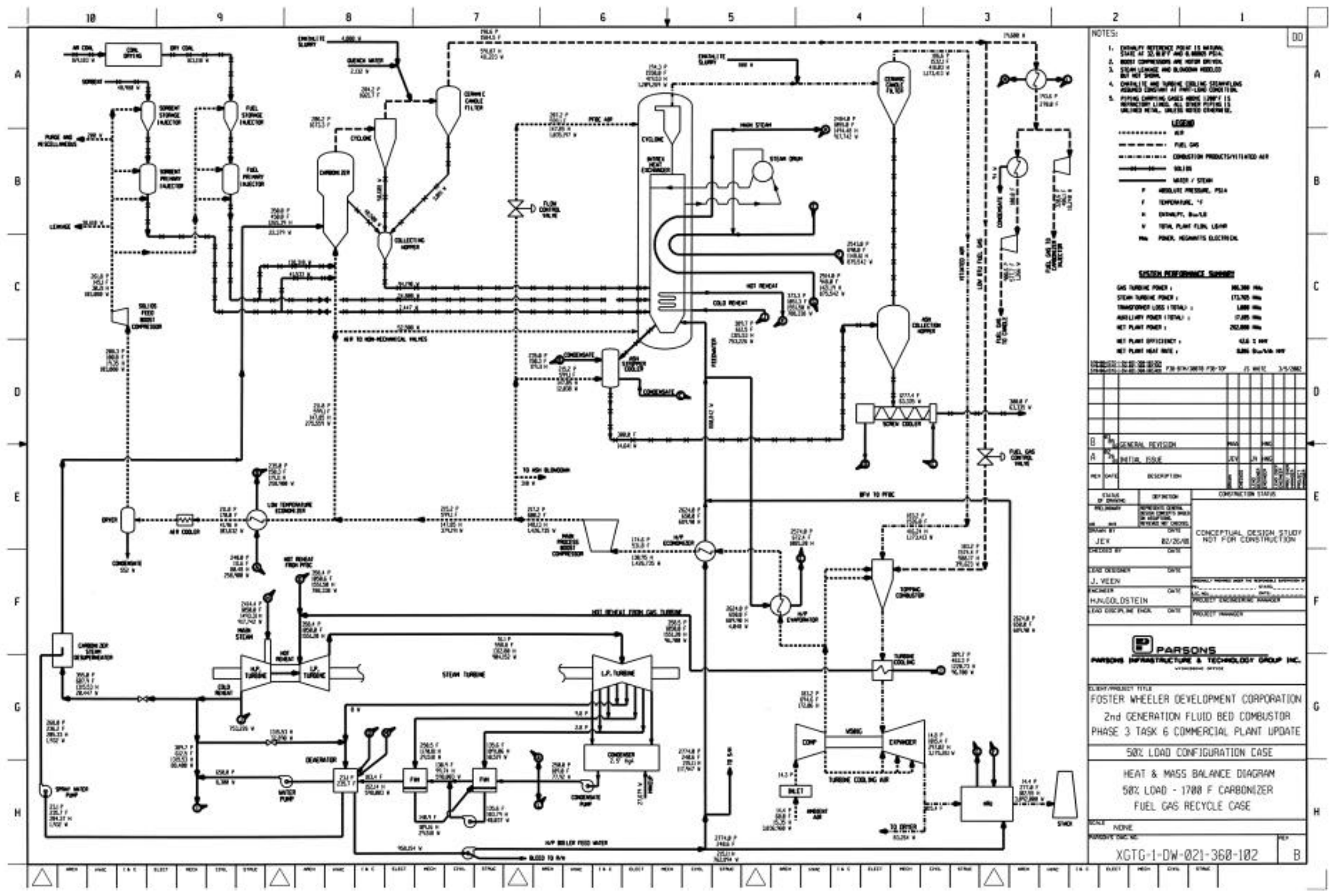

Fig. 7 Baseline Plant at 50\% Load 
The balance of the gas turbine exhaust is used for high-pressure feed water heating (economizer) and steam superheating. Cooling of the compressor air is accomplished in two stages: the first generates 2400 psi steam and the second heats boiler feed water. With parasitic power losses totaling $20.9 \mathrm{MWe}$, the estimated full-load performance of the plant is:

$\begin{array}{lr}\text { Gross Power, MWe } & \\ \quad \text { Gas Turbine } & 239.5 \\ \text { Steam Turbine } & 258.9 \\ \text { Total } & 498.4 \\ \text { Auxiliary Power, MWe } & 20.9 \\ \text { Net Power, MWe } & 477.5 \\ \text { Plant HHV Efficiency, \% } & 48.0 \\ \text { Plant HHV Heat Rate, Btu/kwhr } & 7105\end{array}$

The $50 \%$ part-load condition was achieved by running the $501 \mathrm{G}$ gas turbine at $44.4 \%$ of its design load and the steam turbine at $55.6 \%$ of its design load. With the gas turbine inlet guide vanes having been previously closed, the gas turbine firing temperature has been reduced for further load reduction. Net system efficiency for this part-load condition is estimated at $42.5 \% \mathrm{HHV}$. For this case, "fresh" coal feed was added to the PCFB to augment the carbonizer char flow and maintain the PCFB at 1600EF.

\subsection{Process Flow Design}

Process flow diagrams were prepared by FW for the carbonizer and PCFB legs of the plant and are shown in Figs. 8 and 9 respectively. Coal and dolomite will be fed as a blend to both the carbonizer and the PCFB by the lock hopper type systems shown in these figures. The carbonizer and PCFB both have two gas outlet lines that ultimately connect to four ceramic candle filter vessels. To control gas alkali levels, minus 325 mesh emathlite will be injected into each of these lines downstream of their respective cyclones and upstream of their filter vessels. The injected emathlite will become part of the filter dust cake thereby assuring alkali removal. The filter cake is removed/filter is cleaned by back pulses of clean high-pressure gas. The carbonizer filters are pulse cleaned with recycled syngas that has been extracted from the filter outlet, cooled, and boosted in pressure by compressors. The PCFB filter vessels are pulse cleaned with air from the gas turbine that has been similarly cooled and boosted in pressure. The emathlite will be injected as a $25 \%$ solids- $75 \%$ water slurry. As shown in Fig. 8 , the slurry system consists of two 24-hour storage tanks, a slurry recirculation system, two carbonizer metering pumps with a spare, and two PCFB metering pumps also with a spare. The slurry will be injected at a rate of about $3 \mathrm{gpm}$ into each of two carbonizer syngas lines and at about $0.6 \mathrm{gpm}$ into each of the two PCFB flue gas lines. Each gas line contains two slurry spray nozzles, one of which is a spare. 
Two $100 \%$ capacity bed drain lines are provided at the bottom of the carbonizer and PCFB. The carbonizer bottom drains are used intermittently to prevent oversized material/agglomerates from accumulating in the unit, whereas the PCFB drains are used continuously to maintain bed level/inventory. The bottom-drained material is cooled to $500^{\circ} \mathrm{F}$ by a cooler internal to the carbonizer and two coolers external to the PCFB. Each bottom drain contains block valves and a rotary valve to control drain rates; each carbonizer drain line also contains a delumper that insures all material transferred to the PCFB is of an easily fluidized/circulated size. The carbonizer bottoms drain by gravity to the char collecting hoppers for eventual transfer to the PCFB, whereas the PCFB bottom ash is pneumatically transported to the PCFB filter ash surge hopper.

Two $100 \%$ overflow nozzles at the top of the carbonizer bed allow material to continuously drain (maintains a constant bed level) by gravity to the two char collecting hoppers. Elutriated bed material collected by the two carbonizer cyclones and four filter vessels also drains to the two char collecting hoppers. The latter operate at the filter pressure; and since the bed overflow and cyclone drains originate from points of higher pressure, loop seals/J-valves are provided in each of these lines.

Char-sorbent residue drains by gravity from each char-collecting hopper through a downwardly inclined pipe to a vertical riser/pipe fluidized by nitrogen forming an $\mathrm{N}$ shaped nonmechanical valve. Nuclear level indicators monitor the char level in the collecting hoppers and by varying the riser aeration rate, the char-sorbent level and transfer rate to the PCFB can be controlled. A refractory lined slide valve is provided at the bottom of each char collecting hopper to provide isolation and assist in the control of char-sorbent transfer. An isolation valve and water-cooled screw cooler are provided below the riser aeration point. At shut down, after the plant is depressured, they are used to drain, cool, and transfer all remaining char to the char day bin atop the PCFB feed system.

The $1600^{\circ} \mathrm{F}$ flue gas exiting the two PCFB cyclones is cleaned of particulate by four candle filter vessels operating in parallel. The collected material/fly ash drains to a common surge hopper along with the $500^{\circ} \mathrm{F}$ PCFB bottom ash yielding about a $1300^{\circ} \mathrm{F}$ mix temperature. A water-jacketed restricted pipe discharge provided under the fly ash surge hopper further cools and depressures the fly ash. Ball valves are provided for isolation, and a gate valve operating in conjunction with nuclear level indicators in the fly ash surge hopper controls the ash drain rate. The depressured ash drains by gravity to a surge bin that distributes the material to four 33\% capacity, water-cooled screws that cool the ash to $500^{\circ} \mathrm{F}$ for pneumatic transport to ash silos. 


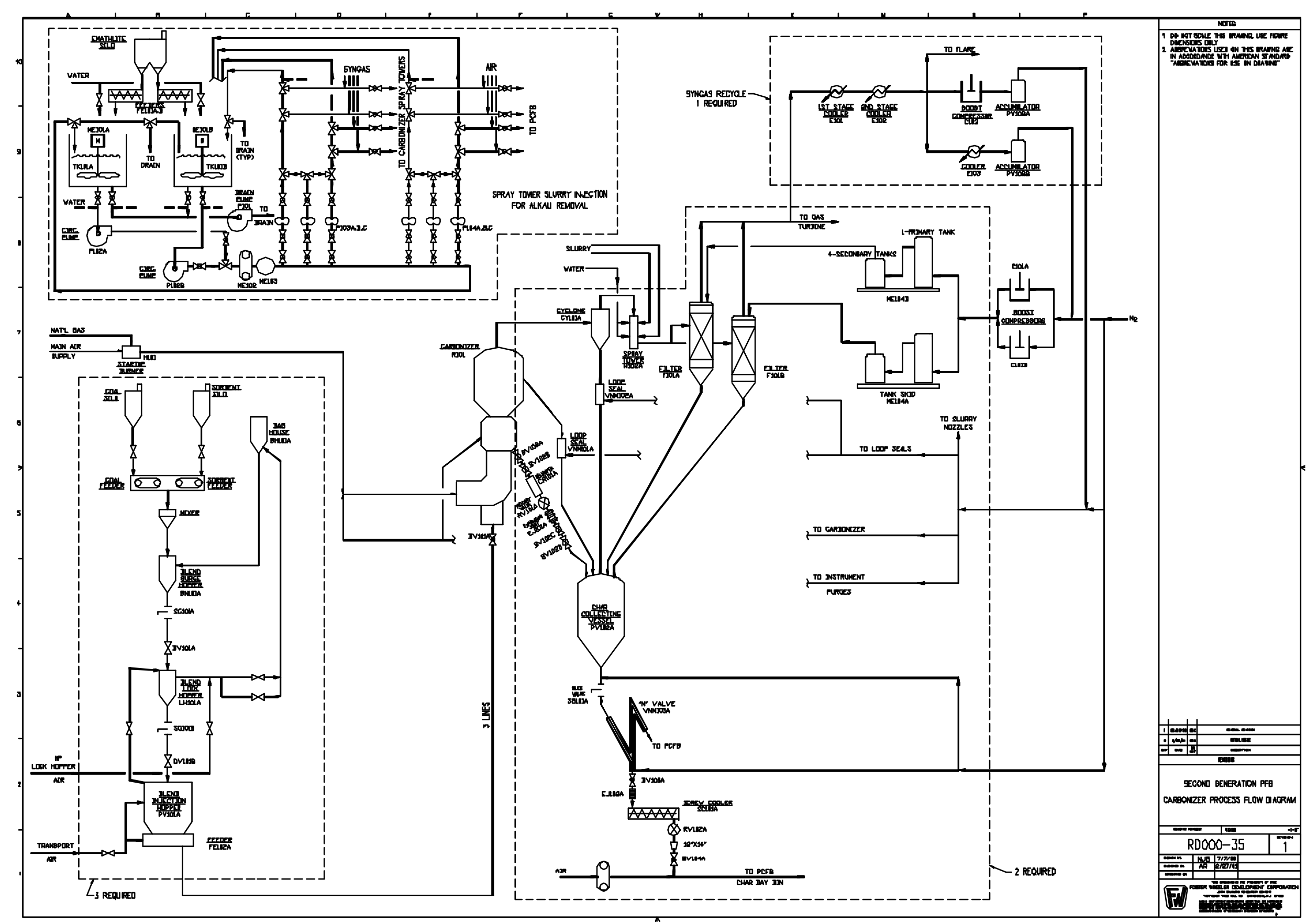

Fig. 8 Carbonizer Process Flow Diagram 




Fig. 9 PCFB Process Flow Diagram 


\subsection{Coal-Sorbent Feed Systems}

The coal and dolomite will be fed as a blend to the carbonizer and PCFB via lock hopper type pneumatic transport feed systems. The carbonizer will utilize three blend feed trains whereas the PCFB will utilize two blend trains and one sand-dolomite trim feed train. The latter will be used at start up to establish a sand bed in the PCFB; during normal operation it can be used to inject dolomite into the PCFB if bed inventory or sulfur capture problems should develop (calcium-to-sulfur molar feed ratio can be quickly changed if necessary). Each of the three carbonizer feed trains can deliver up to $180,000 \mathrm{lbs} / \mathrm{hr}$ of blend with the lock hopper filling and emptying 6 times per hour; with the full load requirement being $341,491 \mathrm{lbs} / \mathrm{hr}$, we essentially have three $50 \%$ capacity feed trains for redundancy.

The coal feed to the PCFB varies from zero at full load to $24,800 \mathrm{lbs} / \mathrm{hr}$ at $50 \%$ load. Each PCFB blend feed train has a maximum flow rate of $76,000 \mathrm{lbs} / \mathrm{hr}$ with its lock hopper filling and emptying 6 times per hour. Although detailed calculations were not performed, at 25\% load the PCFB heat input from char and coal was estimated to be about $980 \mathrm{MMBtu} / \mathrm{hr}$. If only coal was to supply this heat input, say at start up, the required coal flow rate would be about 76,000 lbs/hr. Similarly, if PCFB char flow was temporarily lost at $100 \%$ load, a coal flow rate of about $105,000 \mathrm{lbs} / \mathrm{hr}$ along with about $32,000 \mathrm{lbs} / \mathrm{hr}$ of dolomite $(137,000 \mathrm{lbs} / \mathrm{hr}$ total) would be required. Thus, the two PCFB feed trains provide $100 \%$ redundancy on PCFB heat release rates.

The PCFB start up/trim feed train can deliver sand at up to $74,000 \mathrm{lbs} / \mathrm{hr}$ or dolomite at up to $37,000 \mathrm{lbs} / \mathrm{hr}$ with the lock hopper filling and emptying 6 times per hour.

Fig. 10 depicts the dry lock hopper pneumatic transport type feed systems used by the plant. Each feed train consists of a vent filter, a surge hopper, a lock hopper, and an injector vessel. When depressuring, the lock hopper vents to the filter located atop its train of vessels.

The $1 / 8$ " by zero coal and dolomite used by the carbonizer and PCFB are dried and crushed to size at grade and transported to day bins provided above the feed trains. Weigh belt feeders provided under the day bins control withdrawal of the coal and dolomite and they discharge to a mixer that will blend the material before it discharges into the feed system surge hopper.

\subsection{Carbonizer}

The carbonizer is shown in Fig. 11; it is a 14'-6" ID vertical, refractory lined pressure vessel approximately $47-\mathrm{ft}$ high, with a conical bottom. The unit operates with a $25-\mathrm{ft}$ deep jetting fluidized bed and a superficial gas velocity of approximately $4 \mathrm{ft} / \mathrm{s}$; a $20 \mathrm{-ft}$ tall freeboard is provided to control particulate elutriation rates.

Coal, dolomite, and air enter the unit as a vertical, upward-flowing jet, through a bottom nozzle/manifold assembly. The carbonizer syngas, containing elutriated char and sorbent, leaves the $1700 \mathrm{EF}$ unit through two 28 -in ID nozzles at the top of the vessel. Two 11-in ID bed-overflow nozzles near the midpoint of the vessel limit the bed height to $25 \mathrm{ft}$. A 4-in wide drain annulus provided around the feed pipe allows material to 
drain into a lower, packed bed cooling section. Cooled, recycled syngas is admitted at the bottom, flows up through this section cooling the collected char-sorbent residue, and fluidizes the drain annulus region. Two nozzles at the bottom of the section facilitate draining the unit at shutdown and allow for a small continuous drain during operation. With most of the char-sorbent residue draining through the bed overflow nozzle, the bottom drains are used primarily for bed cleansing, i.e., removing any oversize material accumulating at the bottom of the unit.

There is no heat-transfer surface in the refractory lined carbonizer. The refractory lining consists of a 6 -in inner layer for thermal resistance and a 5 -in outer layer of hard-faced refractory for erosion resistance. 20-in ID manways provide maintenance access to the carbonizer and its bottom cooling section. 


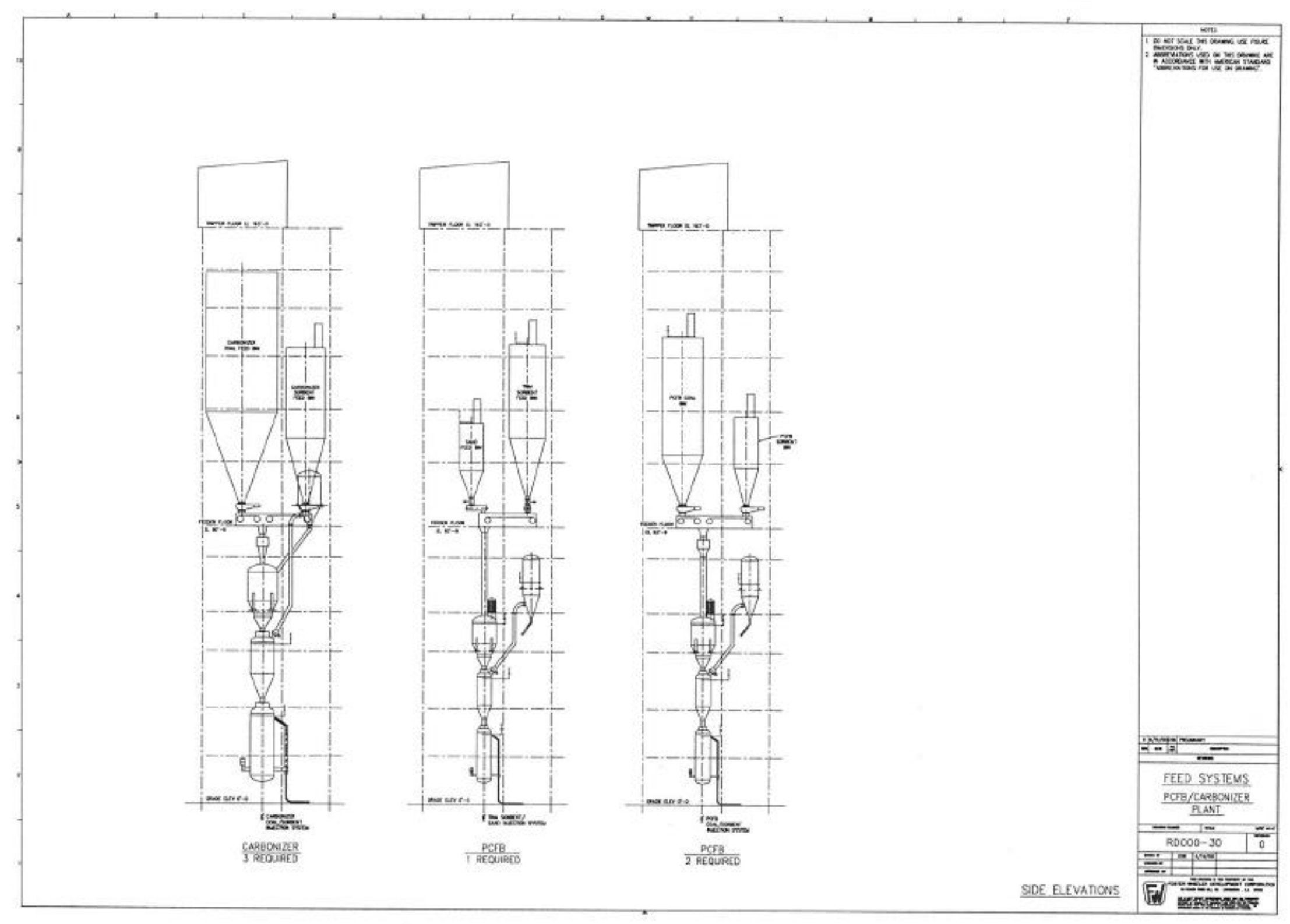

Fig. 10 Lock Hopper Feed Systems 




Fig. 11 Carbonizer Arrangement 


\subsection{PCFB Boiler}

\section{General}

The char-sorbent residue generated in the carbonizer is combusted in the PCFB boiler shown in Fig. 12 with $600^{\circ} \mathrm{F} 294$ psig air supplied from the $501 \mathrm{G}$ gas turbine air compressor. The char heat release totals approximately $1,360 \mathrm{MMBtu} / \mathrm{hr}$ and the PCFB boiler uses this heat to supply $1600^{\circ} \mathrm{F}$ flue gas/vitiated air to the gas turbine topping combustor and 1050EF superheated and reheated steam to a 2400 psig $260 \mathrm{MWe}$ steam turbine. The PCFB boiler consists of a furnace or riser section, two cyclones complete with dip legs and loop seals, three vertically stacked IntrexJ fluidized bed heat exchangers, and solids feed, bypass, and return channels. The PCFB boiler is in essence a conventional circulating fluidized bed (CFB) boiler that has been placed inside a pressure vessel to allow operation with 294 psig air. To minimize the pressure vessel diameter, the IntrexJ units are stacked vertically above each other rather than set side by side at one elevation as would be done with an atmospheric pressure CFB. Char, coal, and lime based sorbent are injected at the bottom of the riser to form a fluidized bed primarily consisting of sorbent and fly ash.

Air is injected into the bed in stages to control NOx formation and the char and coal are combusted, sulfur is released from the fuels as sulfur dioxide, and the lime based sorbent reacts with the latter to capture sulfur as calcium sulfate. Combustion heats the bed to $1600 \mathrm{EF}$ and a resulting $15 \mathrm{ft} / \mathrm{sec}$ flue gas velocity entrains a portion of the bed material. The flue gas with entrained particulate flows vertically up to the top of the riser, exits horizontally through two refractory lined outlet ducts, passes through two cyclones operating in parallel that remove the bulk of the entrained solids, and exits from the top of the cyclones and vessel. Solids captured by the cyclones drain through dip legs and loop seals, and cascade through the three vertically stacked IntrexJ units that cool the solids to approximately $1275 \mathrm{EF}$ for return to the bottom of the riser.

\section{Detail Description}

In plan view the riser section is $5 \mathrm{ft}-61 / 2$ in by $14 \mathrm{ft}-7$ in and the Intrex] units are $7 \mathrm{ft}-6$ in by $14 \mathrm{ft}-7 \mathrm{in}$. The riser is about $161 \mathrm{ft}-6$ in tall, the two lowest Intrex units are about 31 $\mathrm{ft}-10$ in tall, the upper Intrex unit is $27 \mathrm{ft}-10$ in tall, and the given riser and IntrexJ heights all contain $4 \mathrm{ft}$ tall air plenums. The walls, floors, and roofs of the riser, IntrexJ units, and solids bypass and return channels are all formed using waterwall tube construction stiffened by wrap-around type buckstay steel beams as shown in Section C-C.

The riser contains two elevations of wing walls. The lower wing walls contains 7 panels each about $3 \mathrm{ft}$ wide by $46 \mathrm{ft}$ tall, whereas the upper contains 6 panels each also about $3 \mathrm{ft}$ wide by $33 \mathrm{ft}$ tall. The lower wing walls together with all the waterwalls serve as evaporative surfaces; the upper wing walls serve as the primary superheater. Each of the IntrexJ units contains serpentine shaped tube bundles. The topmost or IntrexJ Number 3 tube bundle is $8 \mathrm{ft}-11 \frac{1}{2}$ in tall and serves as the finishing superheater; the next lower Intrexes, Numbers 2 and 1 respectively, serve as finishing and primary reheaters and each contains $10 \mathrm{ft}-9 \mathrm{1} / 2$ in tall tube bundles. The wing walls and tube 
bundles receive and discharge their cooling mediums (e.g., water or steam) from supply and to collection headers provided outside their enclosing waterwalls.

The steam drum is located outside the pressure vessel and two downcomer pipes lead feedwater to three $50 \%$ capacity boiler circulation pumps located at grade. From the pumps the feedwater piping penetrates the pressure vessel and distributes itself among the waterwall and wing wall supply headers. After passing through these heat transfer surfaces, the resulting two-phase water-steam mixture discharges to collection headers and is transported to the drum by riser pipes. Steam enters the PCFB boiler for superheating or reheating and after passing through primary heating surfaces, exits the vessel, passes through temperature control spray stations, reenters the vessel for final heating, and exits for transport to the steam turbine.

Two refractory lined cyclones, each $9 \mathrm{ft}$ in outside diameter, are provided at the top of the riser. The cyclones strip entrained particulate matter from the riser flue gas and discharge their cleaned gases through two 54 in OD refractory lined pipes that penetrate the top head of the pressure vessel and proceed to downstream ceramic candle filters. The hot solids collected by the cyclones drain via refractory lined dip legs and loop seals to feed chutes connected to the uppermost Intrex unit.

Two chutes each approximately $4 \mathrm{ft}$ square in plan view are provided on both sides of each IntrexJ unit as shown in Section D-D. One chute on each side, the feed chute, contains an air plenum whereas the adjoining chute, the bypass chute, does not. Each feed chute contains two wall openings. The lower wall opening discharges to the Intrex] bed, whereas the upper opening discharges to the bypass chute (see Section $\mathrm{K}-\mathrm{K}$ ). If the IntrexJ bed is not fluidized, solids cannot flow from the feed chute into the IntrexJ bed. As a result, solids will collect in the feed chute and reach a level that eventually spills over/through the top wall opening into the bypass chute. When the Intrex] unit is fluidized, solids flow through the lower wall opening into the IntrexJ and the bed levels steadily build up and eventually submerge the tube bundle. A wall opening provided in the Intrex] unit controls the bed height by allowing bed material to also spill over into the bypass chute. The bed discharge opening is located at the top of the tube bundle but below the elevation of the bypass opening in the feed chute (see Section K-K). Solids thus enter the bypass chute from either the feed chute or the bed discharge wall openings. The bypass chute in turn discharges to the feed chute of the next lower Intrex] unit where a similar arrangement is provided. By a proper adjustment of fluidizing velocities in the IntrexJ units and feed chutes, solids can be bypassed around the bed tube bundles to prevent overcooling of solids or over heating of tube bundles at start up.

During normal operation none of the Intrex beds are bypassed; hot solids collected by the cyclones cascade through the 3 IntrexJ units and in so doing are cooled by the waterwall and steam cooled tube bundles. Solids discharge from the bottommost Intrex through an above bed wall opening into the Intrex solids return channel (see Section JJ). The solids together with all the fluidizing air used in the IntrexJ units and feed chutes enter the riser via a wall opening provided at the bottom of the return channel. 


\section{Solids Feed and Draining}

The PCFB boiler is fueled by carbonizer char-sorbent residue entering through two 8 in pipes and by a coal-sorbent blend entering through four 3 in pipes near the bottom of the riser (see Section E-E). Two additional 4 in lines supply sand to the riser and top IntrexJ unit for start up and can also inject sorbent directly to the unit if immediate sulfur capture adjustment is needed. The solids that return from the IntrexJ units are reheated to $1600 \mathrm{EF}$ in the riser and continuously circulate through the unit transferring their heat to the various parts of the PCFB boiler. During their continuous circulation attrition reduces the sizes of the solid particles, and, depending upon feedstock characteristics and operating conditions, about $75 \%$ of the residue eventually escapes the cyclones. To control the inventory of solids circulating through the riser and IntrexJ units, solids are drained from the bottom of the riser via either of two $100 \%$ capacity lines that lead to pressurized water cooled screws located outside and below the enclosing PCFB pressure vessel.

\section{Air Flow Path}

The 600EF 294 psig air enters at the top of the pressure vessel via a 30 in line and flows vertically down the unit through the annular type space defined by the vessel inside diameter and the PCFB boiler. As the air flows inside the vessel, it is distributed among the air plenums provided at the bottom of the riser, feed chutes, IntrexJ units, and return channel as well as riser secondary air injection nozzles. Valves control the airflow to each of these locations, and accessibility for maintenance requires that the valves be located outside the pressure vessel. As a result, the air leaves the vessel, passes through a control device/butterfly valve, and reenters the vessel by piping that feeds each of these users (see Section A-A). In addition to a control device, the riser plenum air piping contains a natural gas fired burner that is used to heat up the unit to ignition temperature at start up.

\section{Pressure Vessel}

The PCFB boiler is contained within a 3 in thick pressure vessel $34 \mathrm{ft}$ in outside diameter (OD) by 197 feet tall. The vessel is designed and fabricated per the ASME Boiler and Pressure Vessel Code Section VIII Division II in SA $537 \mathrm{Cl} 2$ material. The vessel is oriented vertically, bottom supported by a skirt, and a surrounding platform steel structure provides lateral support for resisting wind and seismic loads.

The vessel is designed for a maximum working temperature of $700 \mathrm{EF}$. The combustion air enters at $600 \mathrm{EF}$, and the waterwall operates at the drum saturation temperature of about $680 \mathrm{EF}$. The enclosing pressure vessel has 3 in of insulation and lagging applied to its $34 \mathrm{ft}$ OD keeping the outside surface temperature under 120EF. By having the air sweep the vessel-to-boiler annular space before entering the PCFB boiler, the vessel wall is kept at about 600EF and protected from any flue gas leaks, e.g., any enclosure wall leakage would involve 600EF air flowing into rather than $1600 \mathrm{EF}$ flue gas flowing out of the PCFB boiler. In addition, should any hot solids escape from the PCFB boiler and fall to the bottom of the vessel, the bottom head is protected by a stand off sheet metal liner. 
The PCFB boiler is top-supported inside the pressure vessel; the riser and cyclones are supported from a truss at the top of the unit and they are free to grow downward. The Intrex assembly is also top-supported but from a lower elevation inside the vessel. Since the riser and IntrexJ assemblies are connected at the bottom, the IntrexJ assemblies are supported by spring hangers that absorb differential expansions caused by the two different support elevations. In addition, expansion joints and/or flexibility loops are provided in the various piping and tubing runs located within the unit. Numerous 36 in diameter accessways are provided in the vessel that lead to internal maintenance platforms. Each IntrexJ unit has been provided with sufficient freeboard height that allows individual tube elements to be withdrawn from/lifted up out of the tube bundle should repairs become necessary during the life of the unit. Accessways located at freeboard elevations will enable replacement tube bundle sections to be brought directly into the freeboard regions.

\section{Field Erection}

When empty, the PCFB boiler and its $34 \mathrm{ft} \mathrm{OD} \mathrm{by} 197 \mathrm{ft}$ long pressure vessel weigh over 3,000 tons. Because of the large size and weight, shop assembly and barge shipment of a fully assembled unit is impractical. As a result, the PCFB boiler will be shipped to the site in sections for field assembly. The enclosing pressure vessel will be field fabricated, pressure tested, Code stamped, and placed in position. An $18 \mathrm{ft}$ diameter disk will be cut out of the bottom head and a similar rectangular opening cut in the support skirt. PCFB boiler sections will then be inserted/ lifted into and installed inside the vessel through these openings. Upon completion of the assembly, the skirt section and disk will be welded back into position by the vessel manufacturer. The vessel disk weld will be subjected to $100 \%$ x-ray; and since the operation will be treated as a repair by the original manufacturer, another pressure test will not be required. 


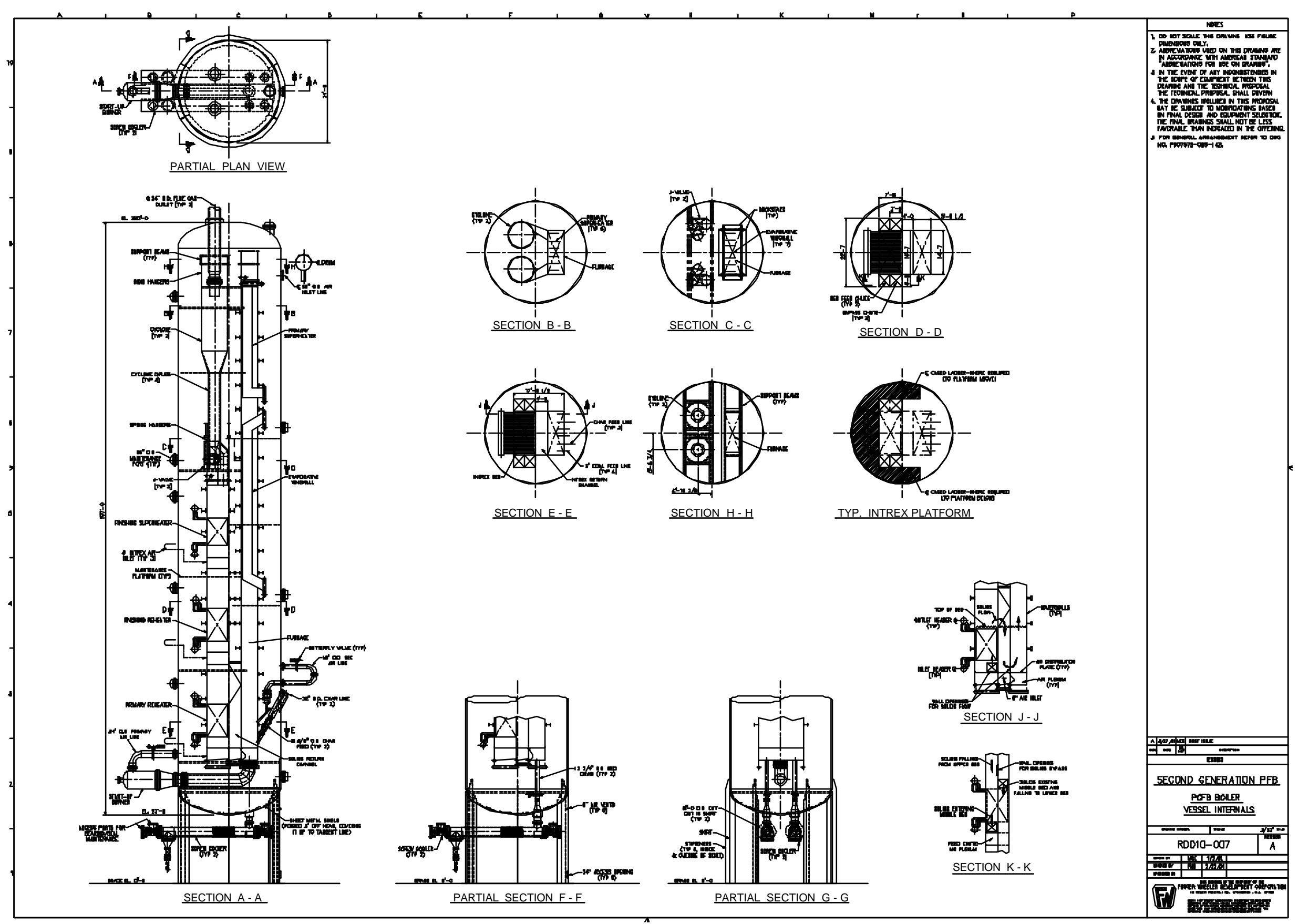

Fig. 12 PCFB Boiler General Arrangement 


\subsection{Ceramic Candle Filter Systems}

The hot gas filter design configuration used for the Carbonizer and PCFB filters is shown schematically in Fig. 13. It uses ceramic candle filter elements, $1.5 \mathrm{~m}$ long and $60 \mathrm{~mm}$ in outer diameter. The hot gas filter consists of stacked arrays of filter elements supported from a common tubesheet structure. The arrays (Item 2) are formed by attaching individual candle elements (Item 1) to a common plenum section. Each candle element has an attached "fail-safe" or "safe guard" device that limits the gas flow and dust emission from a candle if it is damaged. All the gas filtered by the candles comprising this single array is collected in the common plenum and discharged through a pipe to the clean side of the tubesheet structure. Each array of filter elements is reverse-cleaned from a single pulse nozzle source. The individual plenum assemblies (or arrays) are stacked vertically from a common support structure (pipe), forming a four-array filter cluster. The individual clusters are supported from a common, high alloy tubesheet structure and expansion assembly that spans the pressure vessel and divides the vessel into its "clean" and "dirty" gas sides.

Each cluster attaches to the tubesheet structure by a specially designed split ring assembly. The cluster is free to grow down at temperatures. The plenum discharge pipes ducting the filtered gas to the clean gas side of the tubesheet structure are contained within the cluster support pipe and terminate at the tubesheet. Each discharge pipe contains an eductor section. Separate pulse nozzles are positioned over each eductor section. The eductors assist pulse cleaning. During cleaning, the pulse gas is contained within and ducted down the discharge pipe and pressurizes the respective plenum section.

The plenum assembly and cluster (stacked plenums) form the basic modules needed to form large filter systems for electric power generation.

The filter is designed for ease of maintenance. Access into the filter body is provided by four, 36-inch diameter manways. Two diametrically opposite manways are positioned between clusters to access the top level of plenums. Similarly, two diametrically opposite manways are positioned between clusters to access the lower middle level of plenums. The access and maintenance arrangement is illustrated in Fig. 14. At any given platform location, all filters for two adjacent plenums are accessible by rotating the associated cluster. Such rotation is accomplished by entering the vessel head above the tubesheet, disengaging the cluster top flange from the tubesheet and with standard manual rigging attached between the vessel head and cluster top flange, lifting and rotating the cluster. 

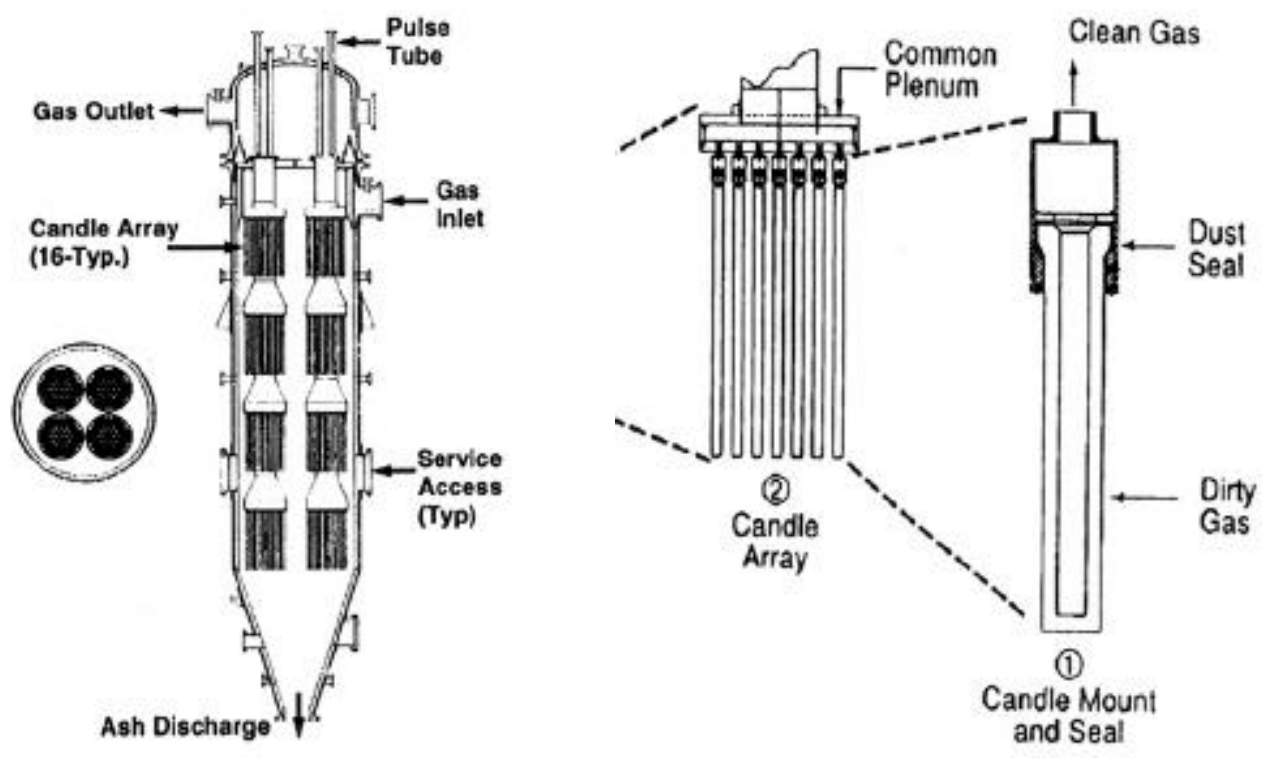

Fig. 13 Candle Filter System Module

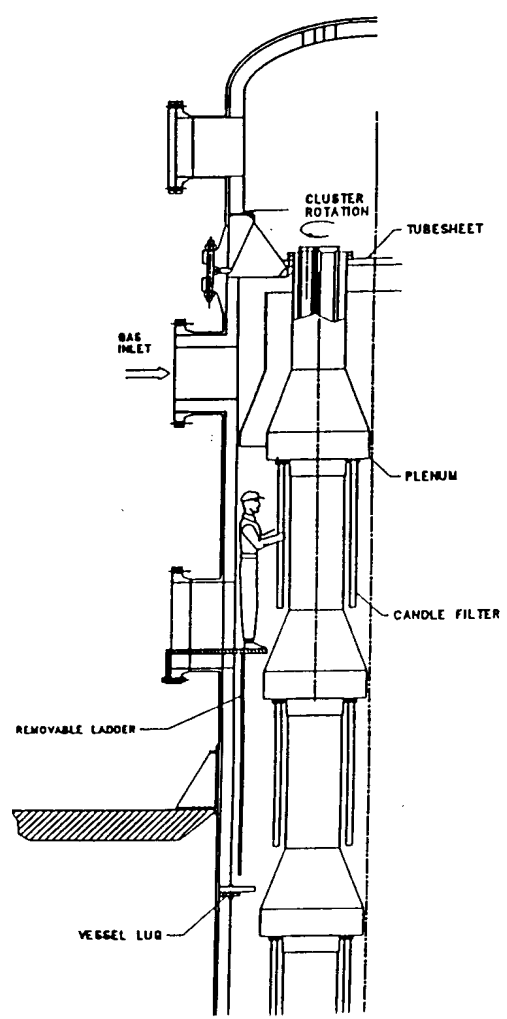

Fig. 14 Hot Gas Filter Maintenance Features 
The carbonizer filter is designed for a nominal operating temperature of $1600^{\circ} \mathrm{F}$, and the inlet and outlet nozzles are radial with horizontal orientations. The vessel and pulse control skid are illustrated in Fig. 15. The main characteristics of the carbonizer filter system are:

- number of vessels: 4

- number of pulse control skids: 4 (each skid arranged on 2 platforms)

- number of pulse gas compressors: 2 (1 operated for normal duty; both operated for maximum duty)

- vessel OD (ft): 10.6

- vessel height $(\mathrm{ft}): 58$

- head height (ft): 11.3

- body height (ft): 46

- gas inlet nozzle nominal size (in.): 38

- gas inlet nozzle center-line location: about 13-ft below top of vessel head

- gas outlet nozzle nominal size (in.): 34

- solids drain nozzle nominal size (in.) 30

- vessel empty wt, each (tons): 134

- vessel loaded wt, each (tons): 163

- pulse control skid size, each $\left(\mathrm{ft}^{2}\right): 350$

The performance of the carbonizer filter system is summarized below based on pulse cleaning conducted on a uniformly distributed schedule:

- face velocity (ft/min): 4.3

- vessel ash storage capacity (hr): 4.5

- maximum pulse frequency $(1 / \mathrm{hr}): 3.1$

- minimum nozzle-to-nozzle trigger pressure drop $^{*}(p s i): 3.3$

- minimum nozzle-to-nozzle baseline pressure drop* (psi): 3.1

- maximum pulse gas consumption (lb/hr): 1360

- maximum gas temperature loss $\left({ }^{\circ} \mathrm{F}\right): 16$

- minimum pulse frequency $(1 / \mathrm{hr}): 2.0$

- maximum nozzle-to-nozzle trigger pressure drop* (psi): 3.9

- maximum nozzle-to-nozzle baseline pressure drop* (psi): 3.6

- minimum pulse gas consumption (lb/hr): 590

- minimum gas temperature loss $\left({ }^{\circ} \mathrm{F}\right): 14$

Both maximum and minimum pulse frequency conditions are listed. 


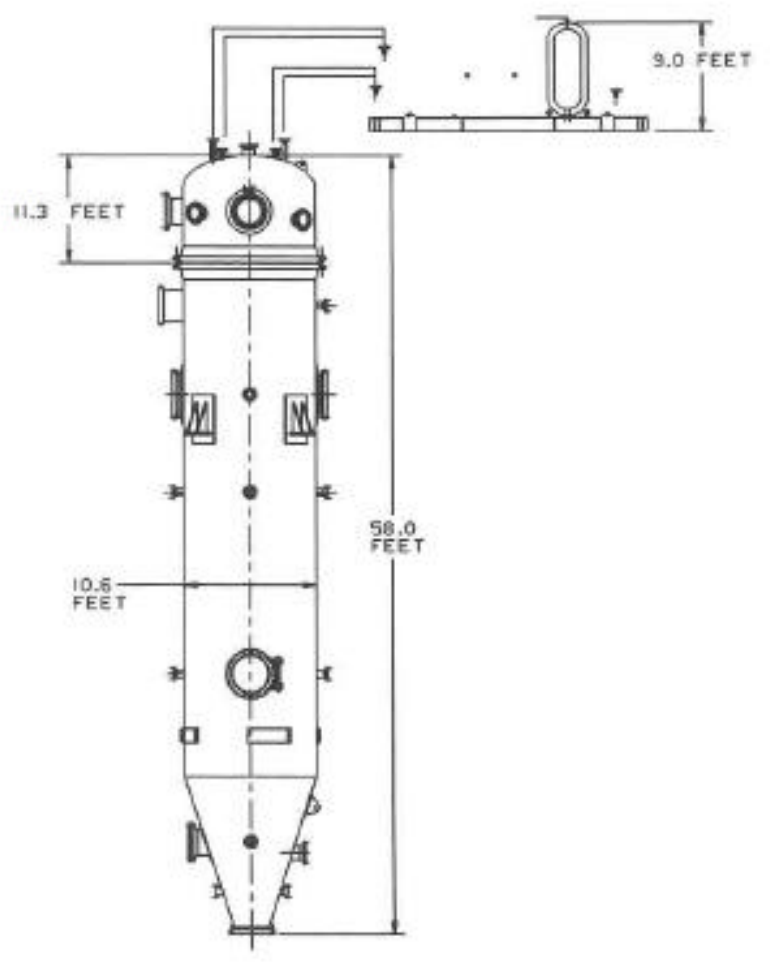

Fig. 15 Carbonizer Filter Vessel and Pulse Control Skid

The PCFB filter is designed for a nominal operating temperature of $1600^{\circ} \mathrm{F}$, and the inlet and outlet nozzles are radial with horizontal orientations. The vessel and pulse control skid are illustrated in Fig. 16. The main characteristics of the PCFB filter system are:

- number of vessels: 4

- number of pulse control skids: 4 (each skid arranged on 2 platforms)

- number of pulse gas compressors: 2 (1 operated for normal duty; both operated for maximum duty)

- vessel OD (ft): 10.9

- vessel height (ft): 61

- head height (ft): 12.2

- body height (ft): 48.7

- gas inlet nozzle nominal size (in.): 44

- gas inlet nozzle center-line location: about 15-ft below top of vessel head

- gas outlet nozzle nominal size (in.): 40

- solids drain nozzle nominal size (in.) 38

- vessel empty wt, each (tons): 146

- vessel loaded wt, each (tons): 175

- pulse control skid size, each $\left(\mathrm{ft}^{2}\right): 350$

The performance of the PCFB filter system is summarized below based on pulse cleaning conducted on a uniformly distributed schedule: 
- face velocity (ft/min): 8.1

- vessel ash storage capacity (hr): 0.6

- maximum pulse frequency $(1 / \mathrm{hr}): 8.0$

- minimum nozzle-to-nozzle trigger pressure drop* (psi): 5.2

- minimum nozzle-to-nozzle baseline pressure drop* (psi): 5.0

- maximum pulse gas consumption (lb/hr): 4911

- maximum gas temperature loss $\left({ }^{\circ} \mathrm{F}\right): 11$

- minimum pulse frequency (1/hr): 3.9

- maximum nozzle-to-nozzle trigger pressure drop $^{*}(p s i): 6.0$

- maximum nozzle-to-nozzle baseline pressure drop* (psi): 5.6

- minimum pulse gas consumption (lb/hr): 1,432

- minimum gas temperature loss $\left({ }^{\circ} \mathrm{F}\right): 8$

Both maximum and minimum pulse frequency conditions are shown.

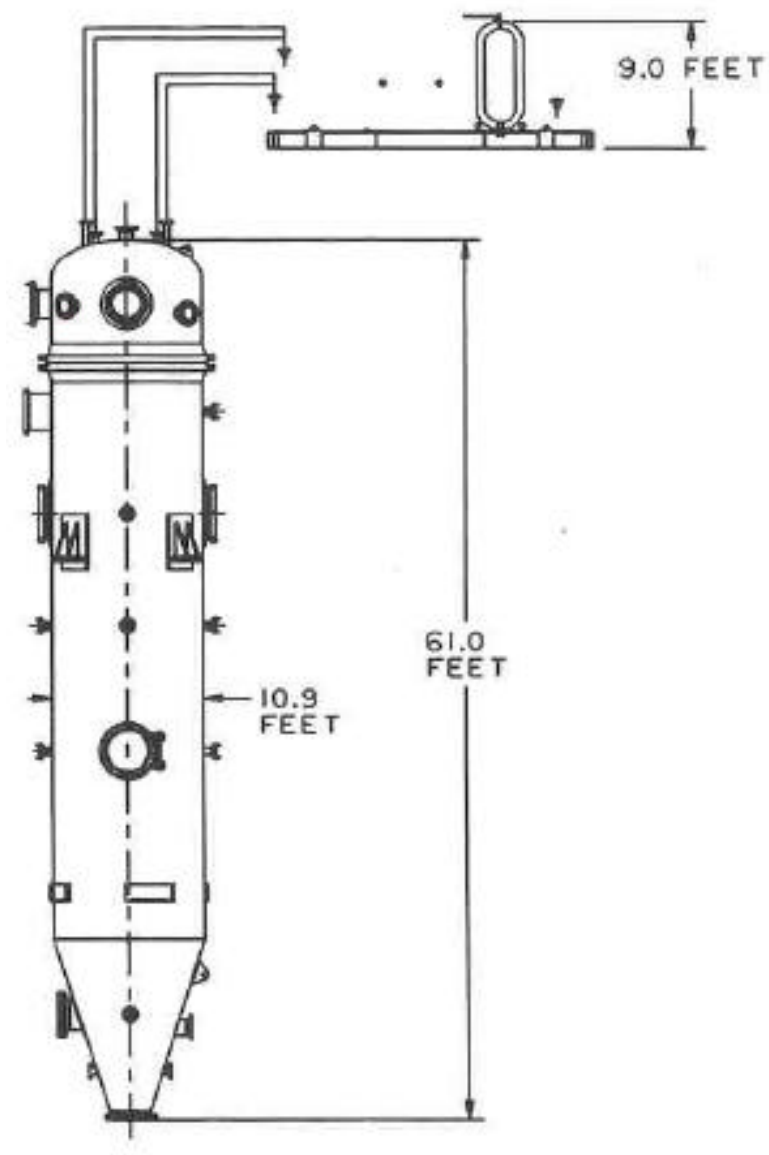

Fig. 16 PCFB Filter Vessel and Pulse Control Skid 


\subsection{W501G Gas Turbine}

The gas turbine is a conventional W501G machine that has been modified to export about $55 \%$ of its airflow to and to import hot syngas and vitiated air from the PFB process.

The modified W501G gas turbine consists of three basic elements: axial-flow compressor, topping combustion system, and turbine expander. These three elements are combined into a single assembly with horizontally split and sectionalized casings, two-bearing rotor support, turbine air cooling system, compensating alignment system and axial-flow exhaust.

The axial-flow compressor design is derived from the W501F compressor. The compressor has 17 stages with advanced profile airfoils and a 19.2:1 pressure ratio. A single variable inlet guide vane (VIGV) assembly is used, together with opening the compressor bleed valves, to avoid compressor surge during start up. The VIGV is also modulated to improve combined-cycle part load efficiency.

With $55 \%$ of the compressor discharge being exported to process the balance of the air is used for cooling various gas turbine components. The air is extracted through 16 topping combustor assemblies arranged circumferentially around the turbine to ensure uniform air flows within the turbine.

For PCFB application, the W501G incorporates 16 dual-fuel topping combustors, each of which is a Multi-Annular Swirl Burner (MASB). Coal-derived syngas from the carbonizer provides the fuel for the topping combustor, and the exhaust gas from the PCFBC, from which some of the oxygen has been depleted, is the vitiated air that provides oxygen.

NOx emissions leaving the MASB include pass-through NOx produced by the PCFB boiler as well as $\mathrm{NOx}$ converted from syngas $\mathrm{NH}_{3}$ within the MASB. As much as $10 \%$ of the NOx in the vitiated air may be reduced to $\mathrm{N}_{2}$ in the MASB, with the remaining $90 \%$ passing through the combustor and out of the plant. The MASB is not expected to produce any thermal NOx.

Syngas, vitiated air, and compressed air flow to and from each combustor are shown in Fig. 17. Compressed air leaves the compressor and enters the housing around each combustor. Some of the air is mixed with vitiated air, and the rest is extracted through a perpendicular nozzle. Vitiated air enters each combustor, where it combines with compressed air to form the oxidizing mixture for the MASB. Except for mixing air, the compressed air is separated from the vitiated air by a containment sleeve. Syngas (or natural gas during start up) is injected into each MASB nozzle and burned, and the products of combustion are delivered to the gas turbine expander through individual transition ducts. 


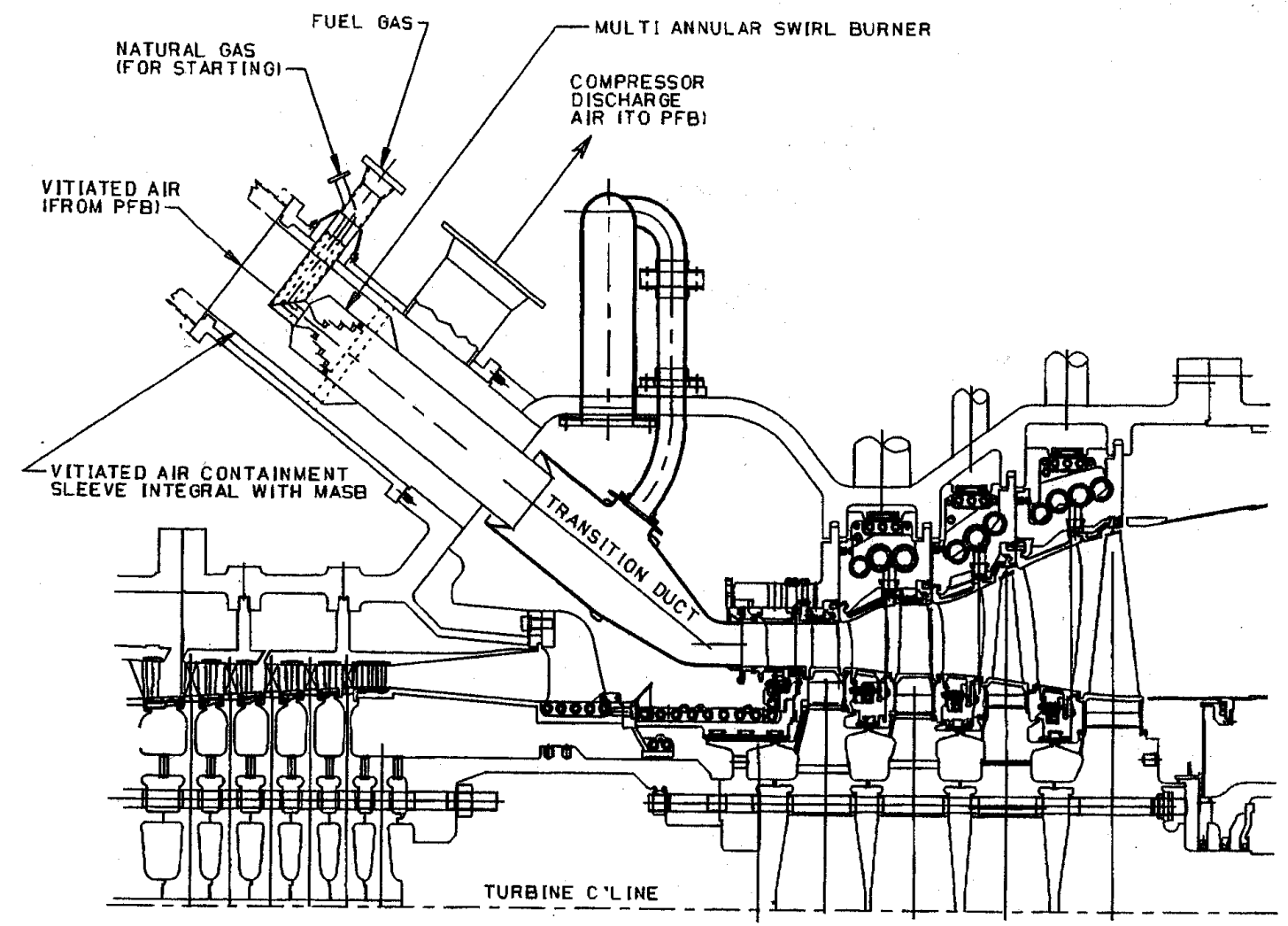

Fig. 17 Syngas Combustor Flow Arrangement

The W501G transitions are steam-cooled to allow the combustion turbine to operate at higher rotor inlet temperatures while maintaining the same burner outlet temperature as W501F-class combustion turbines. Steam that is generated in the PCFB is manifolded into the thin exterior walls of the transitions to cool them. The W501G gas turbine in this PCFB application use about 100,000 lb/h of 500-psia cooling steam, entering around $500 \mathrm{EF}$ and leaving around 1050EF. The hot steam leaving the transition is then returned to the hot reheat steam system to improve the overall efficiency of the combined cycle power plant.

The W501G turbine follows previous W501 designs, with curvic-clutched discs to transmit torque and a four-stage turbine to optimize efficiency. The first three stages are air-cooled. The turbine uses advanced materials such as directionally solidified castings for the first two turbine rows and state-of-the-art electron-beam vapordeposited thermal barrier coatings.

Rotor cooling air is provided by compressor discharge air extracted from the combustor shell. This provides a blanket of protection from hot blade path gases and eliminates excessive contaminants that could block critical cooling passages to the rotor blades. Other compressor discharge air is used to cool the turbine blade ring cavities and vane segments.

Fig. 18 is a plan view arrangement of the gas turbine. The three large ring manifolds for vitiated air, syngas, and compressed air are shown located near the center of the combustion turbine. Finer details, such as enclosures, piping, wiring, fuel system, and 
the bypass system, are not included because they would obscure the view of the major equipment items.

The gas turbine unit occupies a space approximately $154 \mathrm{ft}$ by $108 \mathrm{ft}$. The orientation of the turbine air inlet filter, shown at grade level in the figure, affects both the width and height of the configuration. If a narrower plant footprint is needed, the turbine air inlet filter can also be installed in an overhead orientation, in which inlet air enters the compressor from above.

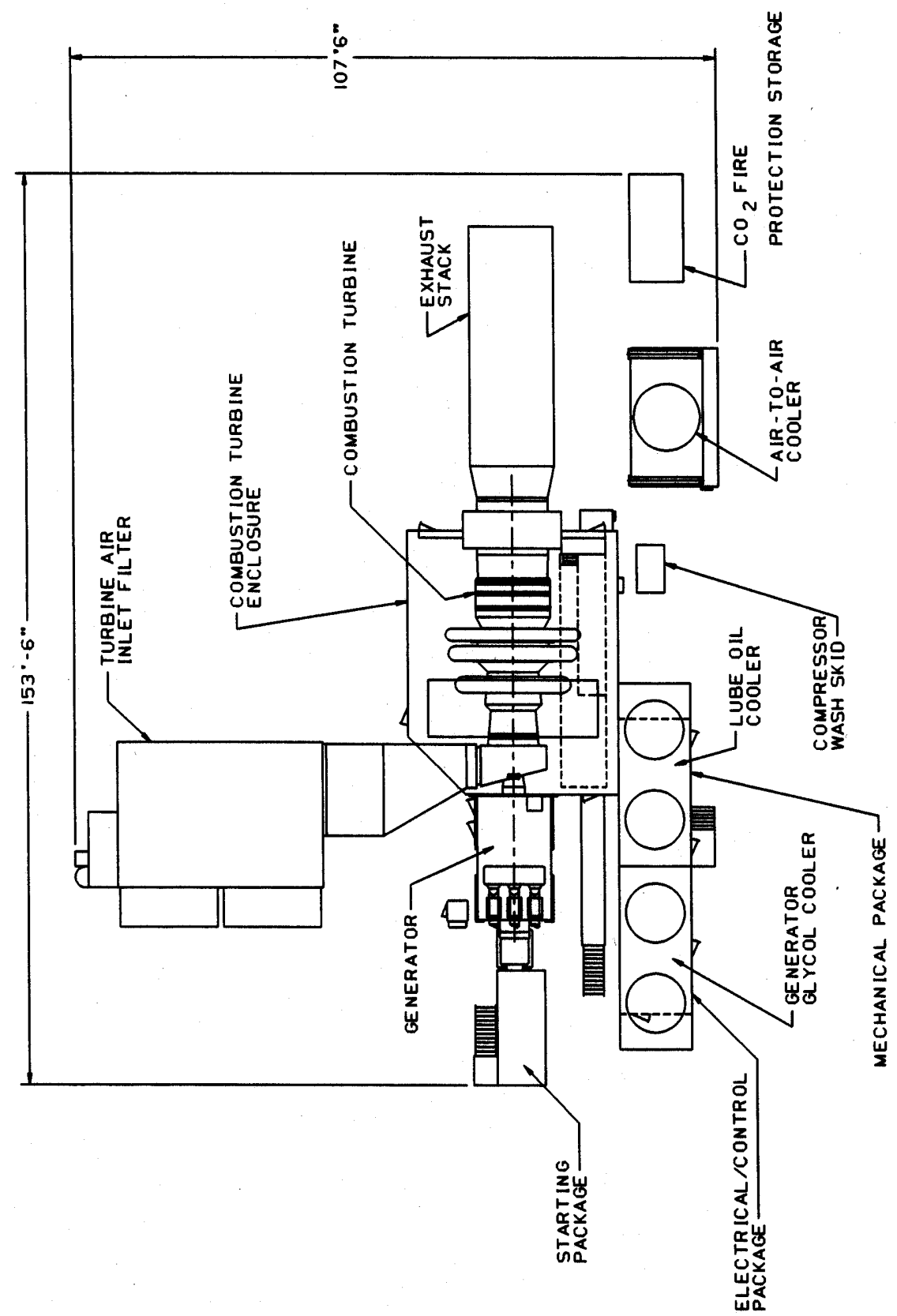

Fig. 18 Plan View of Gas Turbine Installation 
The gas turbine piping and manifolding are configured to send compressed air to the boost compressor and receive syngas from the carbonizer and vitiated air from the PCFB boiler. Three toroidal ("ring") manifolds connect the plant piping for compressed air, syngas, and vitiated air, respectively, with the 16 gas turbine combustors. As shown in Fig. 19, the major axis of each toroidal manifold is aligned with the major axis of the turbine, so that the manifold surrounds the turbine.

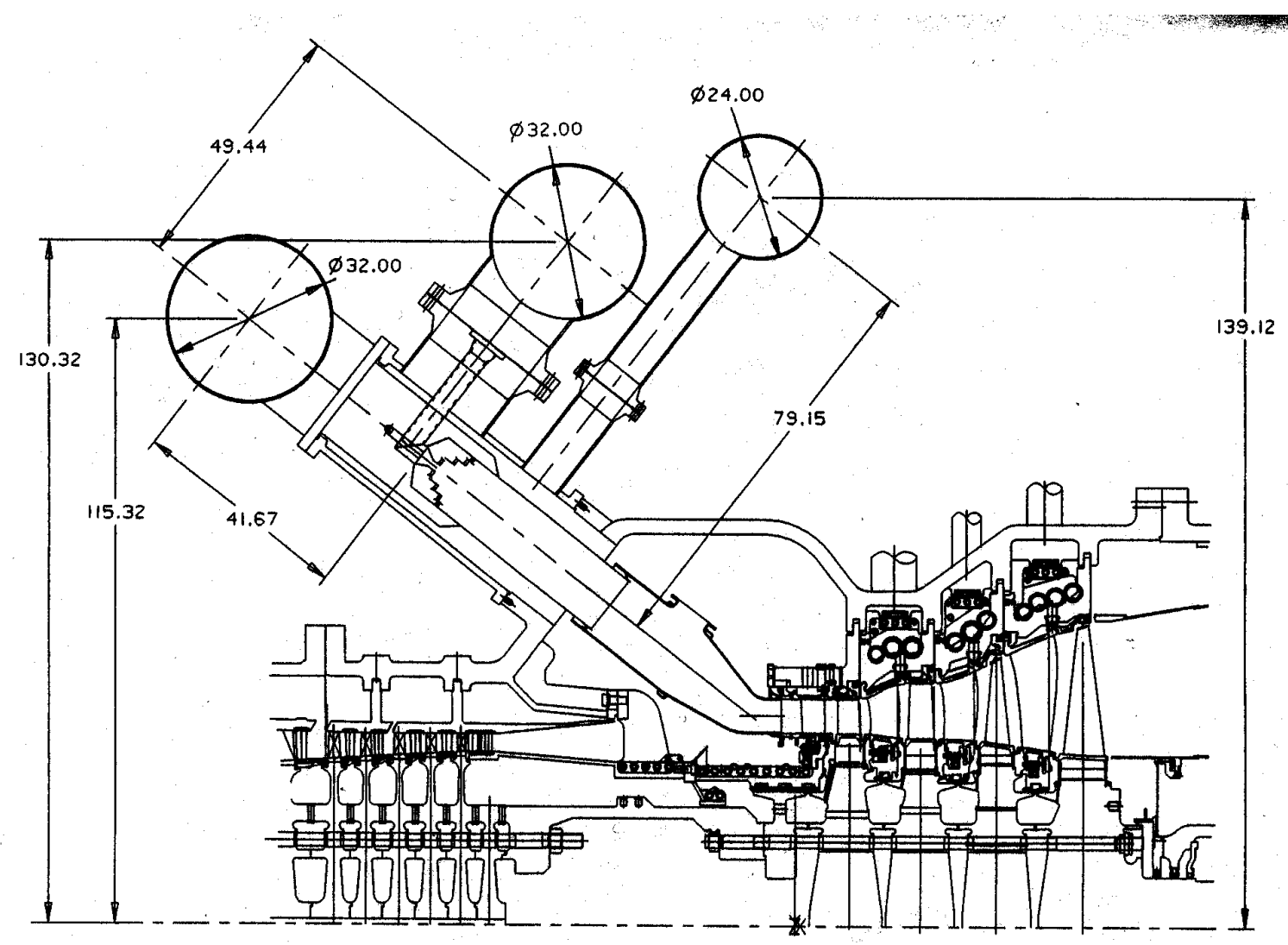

Fig. 19 Syngas Combustor Manifold Connections

\subsection{Plant Control System Design Basis}

Conceptual strategies for starting up, controlling, and shutting down (both normal and abnormal) the plant have been developed based on the valving shown in Fig. 20. Tables 1 through 4 present the strategies, and Section 8 defines the acronyms and abbreviations used in this figure and tables. 


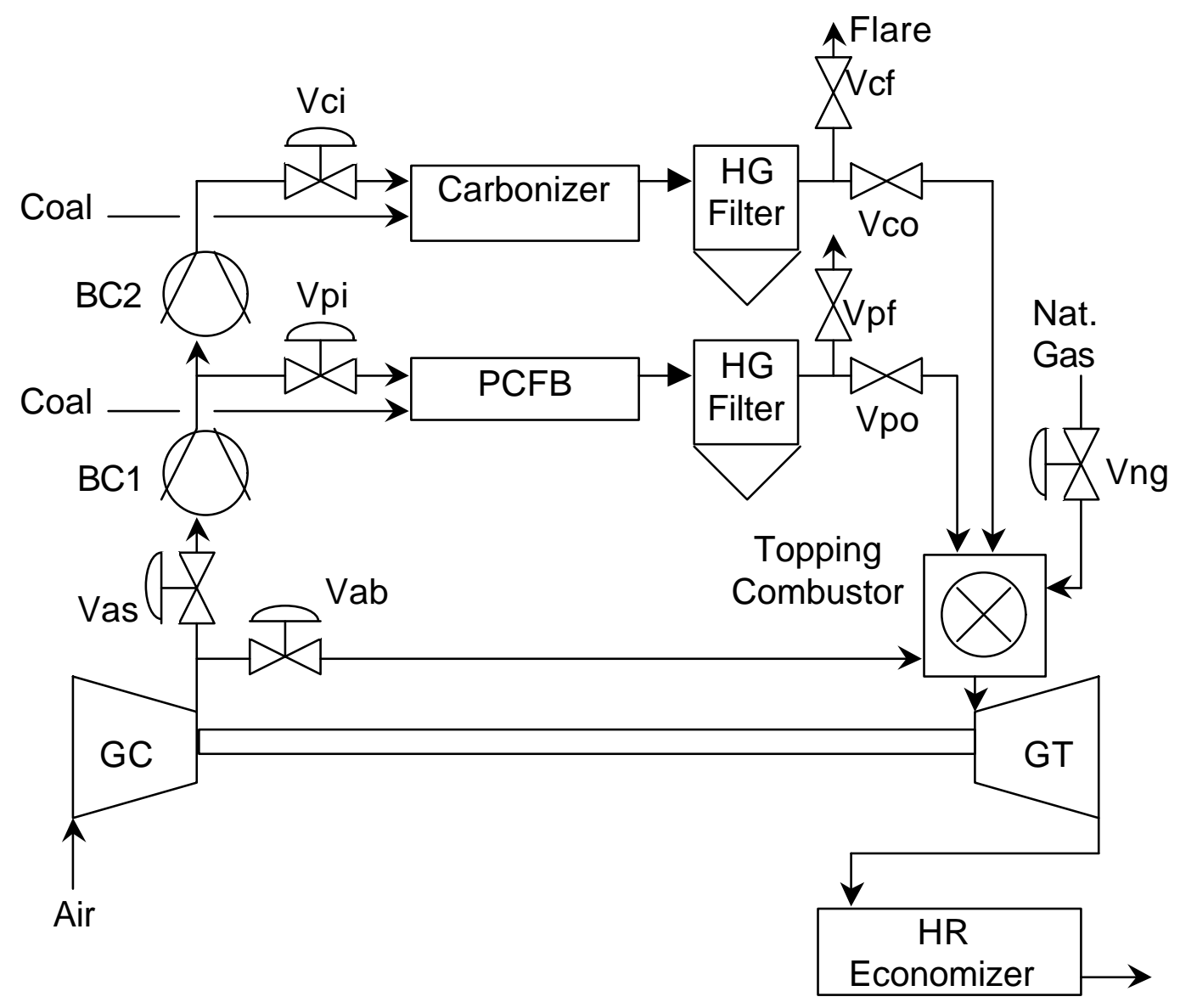

Fig. 20 Plant Control Gas Flow Diagram 


\section{Plant Start}

Table 1 describes the cold start up procedure for the complete plant, including the proposed use of bypasses. Maximum and minimum air flows to and from the W501G compressor and turbine during start up and operation are consistent with normal practice.

Similar procedures would be used for warm start up, such as would occur after an overnight or weekend shutdown, or a hot start up, such as would occur after a brief shutdown following a generator trip or component failure that is quickly remedied. Since equipment temperatures are warmer at the beginning of warm and hot starts, the duration of each step is shorter than for cold starts.

Table 1 Plant Cold Start Sequence

\begin{tabular}{|c|c|c|c|}
\hline Step & Activity & Hours & Valve Lineup \\
\hline 1 & $\begin{array}{l}\text { Start the gas turbine on natural gas, connect it to } \\
\text { the power grid in simple cycle, and increase } \\
\text { power to about } 15 \% \text { load. ( } 15 \% \text { load is the } \\
\text { suggested point at which the transition-cooling } \\
\text { medium is normally changed from air to steam. } \\
\text { Combustor shell pressure and temperature are } \\
165-170 \text { psia and } 665-670{ }^{\circ} \mathrm{F} \text { at this } 15 \% \text { load } \\
\text { point.) }\end{array}$ & $\begin{array}{l}\text { Normal } \\
\text { start time is } \\
20 \text { minutes }\end{array}$ & \begin{tabular}{|l|} 
Vab open to TC \\
Vas closed to BC \\
Vpi closed \\
Vpf closed \\
Vpo closed \\
Vci closed \\
Vcf closed \\
Vco closed \\
Vng open \\
\end{tabular} \\
\hline 2 & $\begin{array}{l}\text { Start BC. Use compressed air from the gas } \\
\text { turbine to pressurize the PCFB and its HGF to } \\
\text { the same pressure as the topping combustor } \\
\text { (TC). }\end{array}$ & $\begin{array}{l}\text { Determined } \\
\text { by vessel } \\
\text { and piping } \\
\text { volumes } \\
\text { and air feed } \\
\text { rate. }\end{array}$ & $\begin{array}{l}\text { Same as prior step plus: } \\
\text { Open Vas \& Vpi }\end{array}$ \\
\hline 3 & $\begin{array}{l}\text { Using compressed air from the gas turbine } \\
\text { together with a start-up burner at the PCFB, } \\
\text { establish air flow and heat the PCFB to } \\
\text { approximately } 1200^{\circ} \mathrm{F} \text { with exhaust returned to } \\
\text { the TC. }\end{array}$ & $\sim 4 \mathrm{hrs}$ & $\begin{array}{l}\text { Same as prior step plus: } \\
\text { Open Vpo }\end{array}$ \\
\hline 4 & $\begin{array}{l}\text { Establish PCFB coal feed and ignition, gradually } \\
\text { shut off the start-up burner, and heat the PCFB } \\
\text { and filter approximately } 1600^{\circ} \mathrm{F} \text {. }\end{array}$ & $\sim 6$ hours & $\begin{array}{l}\text { Same as prior step plus: } \\
\text { Trim Vas and Vab to } \\
\text { increase flow to TC. } \\
\text { Trim Vpi }\end{array}$ \\
\hline 5 & Begin natural-gas-topped PCFB operation. & & $\begin{array}{l}\text { Same as prior step plus } \\
\text { Close Vab. }\end{array}$ \\
\hline 6 & $\begin{array}{l}\text { Use compressed air from the gas turbine to } \\
\text { pressurize the carbonizer and its HGF to the } \\
\text { same pressure as the topping combustor (TC). }\end{array}$ & $\begin{array}{l}\text { Determined } \\
\text { by vessel } \\
\text { and piping } \\
\text { volumes } \\
\text { and air feed } \\
\text { rate. }\end{array}$ & $\begin{array}{l}\text { Same as prior step plus: } \\
\text { Open Vci }\end{array}$ \\
\hline
\end{tabular}




\begin{tabular}{|c|c|c|c|}
\hline Step & Activity & Hours & Valve Lineup \\
\hline 7 & $\begin{array}{l}\text { Using compressed air from the gas turbine } \\
\text { together with a start-up burner in the carbonizer, } \\
\text { heat the carbonizer and bed to about } 1200^{\circ} \mathrm{F} \text { at } \\
\text { a rate of approximately } 150{ }^{\circ} \mathrm{F} / \mathrm{hr} \text {. Activate the } \\
\text { slurry water spray as required to keep the } \\
\text { temperature of the syngas entering the filter } \\
\text { below } 600^{\circ} \mathrm{F} \text { to avoid combustion of any char } \\
\text { inadvertently remaining in the downstream } \\
\text { system. Carbonizer warm-up exhaust gas is } \\
\text { sent to flare. }\end{array}$ & $\sim 6 \mathrm{hrs}$ & $\begin{array}{l}\text { Same as prior step plus: } \\
\text { Open Vcf }\end{array}$ \\
\hline 8 & $\begin{array}{l}\text { Establish carbonizer coal feed and ignition, } \\
\text { immediately ramp to stoichiometric conditions. } \\
\text { Gradually turn off the start-up burner and heat } \\
\text { the carbonizer and hot gas filter to approximately } \\
1600^{\circ} \mathrm{F} \text { at a rate less than } 150^{\circ} \mathrm{F} / \mathrm{hr} \text {. }\end{array}$ & $\sim 6 \mathrm{hrs}$ & $\begin{array}{l}\text { Same as prior step. } \\
\text { Trim Vci \& Vcf as required. }\end{array}$ \\
\hline 9 & $\begin{array}{l}\text { To convert from stoichiometric to } \\
\text { substoichiometric operation, ramp coal flow rate } \\
\text { and adjust syngas pressure to match TC } \\
\text { pressure. }\end{array}$ & $\sim 2 \mathrm{hrs}$ & $\begin{array}{l}\text { Same as prior step. } \\
\text { Trim Vci \& Vcf as required. }\end{array}$ \\
\hline 10 & $\begin{array}{l}\text { Begin syngas-topped PCFB operation. Shut off } \\
\text { natural gas flow to combustion chamber. }\end{array}$ & & $\begin{array}{l}\text { Same as prior step plus: } \\
\text { Reduce Vng to zero. } \\
\text { Open Vco } \\
\text { Close Vcf \& Vng }\end{array}$ \\
\hline
\end{tabular}

\section{Plant Turndown}

Table 2 describes the tentative turndown procedure for the complete plant. Maximum and minimum air flows to and from the W501G compressor and turbine will be consistent with normal practice.

Table 2 Plant Turndown Sequence

\begin{tabular}{|l|l|l|l|}
\hline Step & Activity & Hours & Valve Lineup \\
\hline 1 & $\begin{array}{l}\text { Reduce gas turbine load by reducing syngas } \\
\text { feed rate while closing the GT guide vanes to } \\
\text { maintain constant exhaust gas temperature. }\end{array}$ & & Vas open to BC \\
& $\begin{array}{l}\text { Reduce carbonizer coal and char flows while } \\
\text { increasing coal feed to PCFB to maintain the }\end{array}$ & & Trim Vpi \\
& $\begin{array}{l}\text { PCFB temperature around } 1600^{\circ} \mathrm{F} \text {. Operate Vpi } \\
\text { and Vco together to maintain proper flow } \\
\text { balance between carbonizer and PCFB. }\end{array}$ & Vpf closed \\
& $\begin{array}{l}\text { Vpo open } \\
\text { (At the end point of this step, GT inlet air flow is } \\
\text { about 70-75\% of GT baseload value, and GT net } \\
\text { power is about } 65 \% \text { of GT baseload value. }\end{array}$ & & Vci open \\
& Combustor shell pressure and temperature are \\
& $200-210$ psia and $\left.720-730^{\circ} \mathrm{F}.\right)$ & & Trim Vco \\
\hline
\end{tabular}




\begin{tabular}{|l|l|l|l|}
\hline Step & Activity & Hours & Valve Lineup \\
\hline 2 & $\begin{array}{l}\text { Reduce syngas feed rate to reduce GT power } \\
\text { output to about 15\% GT load. } \\
\text { (At the end point of this step, GT net power is } \\
\text { about 16\% of GT baseload value. Since GT } \\
\text { power is above 15\%, the transition cooling } \\
\text { medium does not need to change from steam to } \\
\text { air. Combustor shell pressure and temperature } \\
\text { are 165-170 psia and 665-670 } \text { F.) }\end{array}$ & Same as in prior step. & \\
\hline 3 & $\begin{array}{l}\text { Reduce coal flow to PCFB to reduce PCFB } \\
\text { steam generation. GT conditions unchanged. }\end{array}$ & & Same as in prior step. \\
\hline
\end{tabular}

\section{Plant Normal Shutdown}

Table 3 describes the normal shutdown procedure for the complete plant. Maximum and minimum air flows to and from the W501G compressor and turbine during shutdown are consistent with normal practice.

Table 3 Plant Normal Shutdown Sequence

\begin{tabular}{|l|l|l|l|}
\hline Step & Activity & Hours & Valve Lineup \\
\hline 1 & $\begin{array}{l}\text { Reduce power to 25\% of rated plant load using } \\
\text { the procedure described under "Plant } \\
\text { Turndown." }\end{array}$ & & $\begin{array}{l}\text { Vas open to BC } \\
\text { Vab closed to TC } \\
\text { Trim Vpi } \\
\text { Vpf closed } \\
\text { Vpo open } \\
\text { Vci open } \\
\text { Vcf closed } \\
\text { Trim Vco } \\
\text { Vng closed }\end{array}$ \\
\hline 2 & $\begin{array}{l}\text { Gas turbine power will be just above 15\% of } \\
\text { rated load. Switch from steam cooling to air } \\
\text { cooling of the GT transition. }\end{array}$ & & $\begin{array}{l}\text { Same as prior step. } \\
\text { Cut off coal and air flow to the carbonizer, and } \\
\text { char transfer to PCFB. . }\end{array}$ \\
\hline 4 & $\begin{array}{l}\text { Open natural gas flow to TC to enable GT } \\
\text { operation after the syngas was pulled out. }\end{array}$ & & $\begin{array}{l}\text { Same as prior step, plus: } \\
\text { Close Vci } \\
\text { Close Vco } \\
\text { Close char transfer } \\
\text { valves }\end{array}$ \\
\hline
\end{tabular}




\begin{tabular}{|l|l|l|l|}
\hline Step & Activity & Hours & Valve Lineup \\
\hline 5 & $\begin{array}{l}\text { With the carbonizer isolated and topping } \\
\text { combustion ended, reduce coal flow to the } \\
\text { PCFB. } \\
\text { Switch on the start up burner during the } \\
\text { reduction in coal flow (coal will be cut off at } \\
1450 \text { 'F) to provide reduced steam flows to } \\
\text { hasten the cool-down of the steam turbine. } \\
\text { Continue minimum steam generation via the } \\
\text { start up burner. }\end{array}$ & Same as prior step. \\
\hline 6 & $\begin{array}{l}\text { Once the steam turbine has cooled, Shut off the } \\
\text { start up burner. }\end{array}$ & & \\
\hline 7 & $\begin{array}{l}\text { Divert part of the air flow from the PCFB to the } \\
\text { TC. Purge the PCFB leg of the plant with air. }\end{array}$ & & Same as prior step. \\
\hline 8 & $\begin{array}{l}\text { As the PCFB leg of the plant depressurizes to } \\
\text { ambient, simultaneously depressurize the } \\
\text { carbonizer leg of the plant to the flare. }\end{array}$ & Same as prior step, plus: \\
Partially open Vab
\end{tabular}

\section{Plant Abnormal Shutdown}

The sudden loss of electrical load causes rapid acceleration of the gas turbine, which must be stopped in order to prevent catastrophic damage. The gas turbine is protected from damage during abnormal shutdowns by syngas piping and air bypass systems, the portions of the piping system that include valves Vas, Vab, Vpo, and Vco. (See Figure 20.)

The syngas system contains relatively large valves to regulate or shut off the flow of fuel to the topping combustors in the event of a plant upset, change of load, or loss of load. An additional system of valves is required to ensure overspeed protection for the gas turbine. 
At the first instant of load loss, the fuel gas valve (Vco) quickly closes to interrupt gas flow to the turbine, bypassing the fuel gas to flare. Upstream of the carbonizer, air is prevented from entering by the actions of the Air Bypass System. At the same time, the compressed air bypass valve (Vab) opens as the compressed air supply valve (Vas) closes, interrupting the hot vitiated air flow to the turbine and bypassing cooler compressed air to the topping combustor. The closing of the compressed air supply valve (Vas) also stops air from entering either the carbonizer or the PCFB, and also stops the supply of transport air, resulting in cessation of coal feed and char transport. With neither fuel nor air entering the carbonizer or PCFB, the reactions in these large vessels gradually reduce to zero as their gaseous contents are vented and flared. By adjusting the air bypass valve (Vab), the compressor pressure ratio is elevated, increasing compressor work to aid in the deceleration process.

Table 4 describes the abnormal shutdown procedure for the complete plant, such as would occur after a sudden loss of load. Maximum and minimum air flows to and from the W501G compressor and turbine during abnormal shutdown are consistent with normal practice.

Table 4 Plant Abnormal Shutdown Sequence

\begin{tabular}{|l|l|l|l|}
\hline Step & Activity & Hours & Valve Lineup \\
\hline 1 & The following valve actions happen & & Vas closed to BC \\
& simultaneously. & & Vab open to TC \\
& Shunt compressor exit to topping combustor & & Vpi closed \\
& (Switch valve Vas \& Vab) & Vpf open \\
& Shut off air to carbonizer (Close Vci) & Vpo closed \\
& Shut off air to PFBC (Close Vpi) & Vci closed \\
& Depressurize plant at slow controlled rate using & & Vcf open \\
& valves Vcf and Vpf & Vco closed \\
\hline 2 & $\begin{array}{l}\text { Purge and cool down plant by steps 9 through } \\
\text { 11 of Table 3 (Plant Normal Shutdown } \\
\text { Sequence) }\end{array}$ & & Vng closed \\
\hline
\end{tabular}

\subsection{Plant Arrangement}

The total plant site occupies approximately 180 acres, with the power island itself occupying approximately 3 acres. As in a PC-fired plant, the smaller area occupied by the combustion equipment is overshadowed by the requirement to bring feedstocks into the plant and to provide interconnecting piping, access roads, parking, plant administration, and a reasonable working space between plant systems.

Overall Site Plan (Fig. 21): The second-generation PFB combustion power plant is on a relatively level site adjacent to a navigable waterway, with both rail and highway access. The prevailing wind is from the southwest.

Coal and dolomite are delivered to the site by barge and then transported from the barge unloader to a transfer point by belt conveyor. During normal operation, coal or 
dolomite is delivered directly to the stacker/reclaimer conveyor (35), which is perpendicular to the barge unloader docking area. With the stacker/reclaimer in this position, the coal and dolomite storage area are located to the north of the main power island. If the stacker/reclaimer is inoperable at the time of barge delivery, coal or dolomite can be deposited directly in their inactive storage piles by emergency stackout conveyors. The coal pile shown is for about 30-days' storage. Dolomite is delivered pre-ground, and stored in silos. A nominal 14-day supply is maintained on hand. Coal and dolomite storage capacities can be increased up to 3 months, if required.

From storage, coal is sent to the crusher building at the west end of the stacker/ reclaimer conveyor. It is crushed and conveyed to 24-hour storage silos at the east end of the power island. Coal from the silos is conveyed to the preparation building for final crushing, drying, and screening. This building also houses the carbonizer and PCFB lock hopper type pneumatic transport feed systems for both. The dolomite (or limestone) storage silos are located nearby to the east, with short runs of pipe feeding the sorbent pneumatically to the feed trains.

Ash from the two modules is mechanically conveyed to four ash storage silos on the east side of the power island. Ash is removed from the site by truck, using a dedicated ash haul road with an independent plant entrance. A truck scale along the haul road weighs ash trucks entering and leaving the site.

The gas turbine is located to the west of the PCFB boiler. The gas turbine discharge is ducted to the HRU on the west side of the gas turbine. The flue gas from the HRU is then ducted to a stack.

The steam turbine is south of the gas turbine, directly adjacent. Generator leads exit both turbine buildings along the west wall. A common transformer area is located outdoors, west of the end of the combined gas/steam turbine building. From this area power is transmitted overhead to an adjoining substation. By positioning the gas and steam turbines as shown, a common transformer area is created, minimizing bus duct and transmission leads.

A rail spur services the turbine building, providing for heavy equipment installation and removal during and after plant construction.

A maintenance shop building at the southwest corner of the power island houses a laboratory and electrical, instrument, and machine shops.

A two-floor administration building adjacent to the turbine and maintenance buildings houses the plant access and locker room area at grade, with administrative offices on the second level. A parking area for plant personnel is south of the administration building.

A one-story structure located north of the power island structure houses water treating equipment. A building extension, at grade and to the east, houses the auxiliary boilers and emergency diesel generator. 
A river water intake structure at the river's edge east of the power island building provides water to the cooling towers and to the makeup water and pretreatment building. In this building, between the river water intake structure and the steam turbine building, river water is treated and stored awaiting use by the demineralized water system water treating building.

A multi-cell evaporative mechanical draft cooling tower is positioned to the south of the steam turbine building to minimize the length of circulating water piping that carries cooling water to and from the steam turbine condenser. Makeup water is pumped to the cooling towers from the intake structure. A structure adjacent to the cooling towers houses associated electrical switch gear and chlorination equipment. Truck access is provided for chemical delivery and circulating water pump maintenance.

A fuel oil storage tank, surrounded by an earthen dike north and east of the makeup water and pretreatment building, can be supplied with oil by either rail car or truck. A rail spur is provided for tank car shipments. A fuel oil pump house is east of the diked area. Oil piping can be carried back to the power island along a nearby pipe bridge.

A wastewater treatment facility is located north of the oil storage tank area. Wastewater retention ponds are positioned to the east, away from the main power island. Rain water runoff from both the coal and dolomite storage piles is collected in these retention ponds and treated. Other contaminated water is also stored and treated for release.

A syngas flare stack is shown to the east of the oil storage tank in an isolated area of the site. An east-west pipe bridge connects the flare stack with the main pipe bridge on the power island.

Power Island - Plan at Grade (Fig. 22): The Plan at Grade drawing provides additional detail and depicts equipment located at grade. It also shows equipment above grade in "phantom" lines.

Stair towers along the north and south side of the PCFB bay provide access to the various floor levels of the coal preparation building as well as the PCFB and carbonizer vessels. A phantom line outlines the various vessels that make up the steam generation modules above.

A single-story structure housing the plant compressors sits directly to the north of the PCFB bay. The compressors are centrally located, as they serve the carbonizer, the coal and dolomite injection systems, and the filter backpulse system. The booster compressors take their air supply from main compressed air piping that is carried on the pipe bridge overhead. Also within this building are the PCFB start-up air heaters. A refractory lined pipe connects the heaters to a compressed air line that supplies primary air to the PCFB. There are three boiler feedwater recirculation pumps below the PCFB vessel.

Eight ash screw coolers are located at grade, two under the char $\mathrm{N}$ valves, two under the PCFBC vessel, and four under the PCFB fly ash drain bin. 
A switch gear room is located south of the PCFB bay, in the electrical/control/admin building. The $480-\mathrm{V}$ and $4160-\mathrm{V}$ switch gear is housed in this area, providing power for the steam generation island as well as the coal preparation building.

The combined gas and steam turbine building is a high-roof configuration. A high bay over the turbines allows an overhead bridge crane to service the turbines. Each turbine has its own laydown space allocated nearby. There is truck access to both north and south walls of the power island, to move turbine components. An acoustical enclosure surrounds the combustion turbine and the topping combustors. The turbine air inlet directly north of the enclosure is positioned vertically. The combustion turbine exhaust is ducted to the HRSG, directly east of the turbine building, then to the stack. Transformers are in an area west of the turbine buildings, allowing for easy transmission of power to the substation. Power is returned from the substation to the two smaller auxiliary transformers shown to the south. These transformers power the 13.8-kV switch gear in the west end of the steam turbine building.

The steam turbine area lies directly south of the combustion turbine area. Rail access is provided at the southwest corner of the building with an equipment hatch above. The steam turbine has a two-flow, side-exhaust configuration, with "side-saddle" condenser units. This configuration does not require a deep excavation below the turbine, along with a high and massive pedestal. A pit housing the lube oil system is east of the turbine pedestal. The four boiler feedwater pumps, two mains and two boosters, are positioned farther to the east. The condensate pumps are shown on one side of the turbine.

The two bays east of the boiler feedwater pumps house the makeup water treatment and condensate demineralizer equipment. An acid and caustic truck unloading station is outside the east wall of the water treatment area.

The auxiliary boilers are housed in a single-story structure east of the water treatment area. An emergency diesel generator is in an attached structure adjacent to the auxiliary boiler building. The demineralized water storage tank is between the auxiliary boiler and plant access road to the east.

The grade level plan shows an area in the administration building reserved for plant access control and shower/locker rooms. A room in the southeast corner of the building houses the heating, ventilating, and air conditioning (HVAC) equipment required to condition the air in the administration building and the control complex area.

A stair tower and elevator in the northeast corner of the administration building serve both the administration and the turbine building/control complex areas. A stair tower in the southwest corner of the administration building provides a second means for reaching or leaving the second floor.

Power Island-Auxiliary Plans Above Grade: A series of auxiliary plan and elevation views are presented in Figs. 23 and 24. Each auxiliary plan represents two discrete elevations, as noted. The top two elevations are only shown for most but not all of the structure; the part of the structure housing the coal preparation equipment only rises to a final floor elevation of $247^{\prime}-0$ " (the roof is at approximately $275^{\prime}-0$ "). 
The auxiliary plans start at the bottom of the tall structure housing the PCFB, carbonizer, filters, and coal preparation vessels and piping. This structure is comprised of 32 bays, each nominally 25 feet square. For each plan, starting at the west end of the structure, eight bays (two by four) house the coal crushing and drying equipment and piping. This includes the mills or crushers at the lowest elevation (grade), with silos, day bins, cyclone separators, etc. arranged above at elevations to provide a continuous flow path for the coal as it is crushed and dried.

The second group of eight bays houses the carbonizer and its hot gas filters, ash hoppers, etc. The third group of eight bays houses the PCFB. The final group of eight bays houses the hot gas filters serving the PCFB, along with the ash collection vessels.

Power Island-Sections: Section AA shows a longitudinal view of the power island from east to west, and from grade up to the roof line. The section spans the entire structure from the stack to the east to the coal preparation bays on the west.

Section BB shows a transverse view from north to south. The view is taken at the west end of the structure, and thus shows the coal preparation equipment in detail, with other equipment revealed behind as appropriate for the view. 


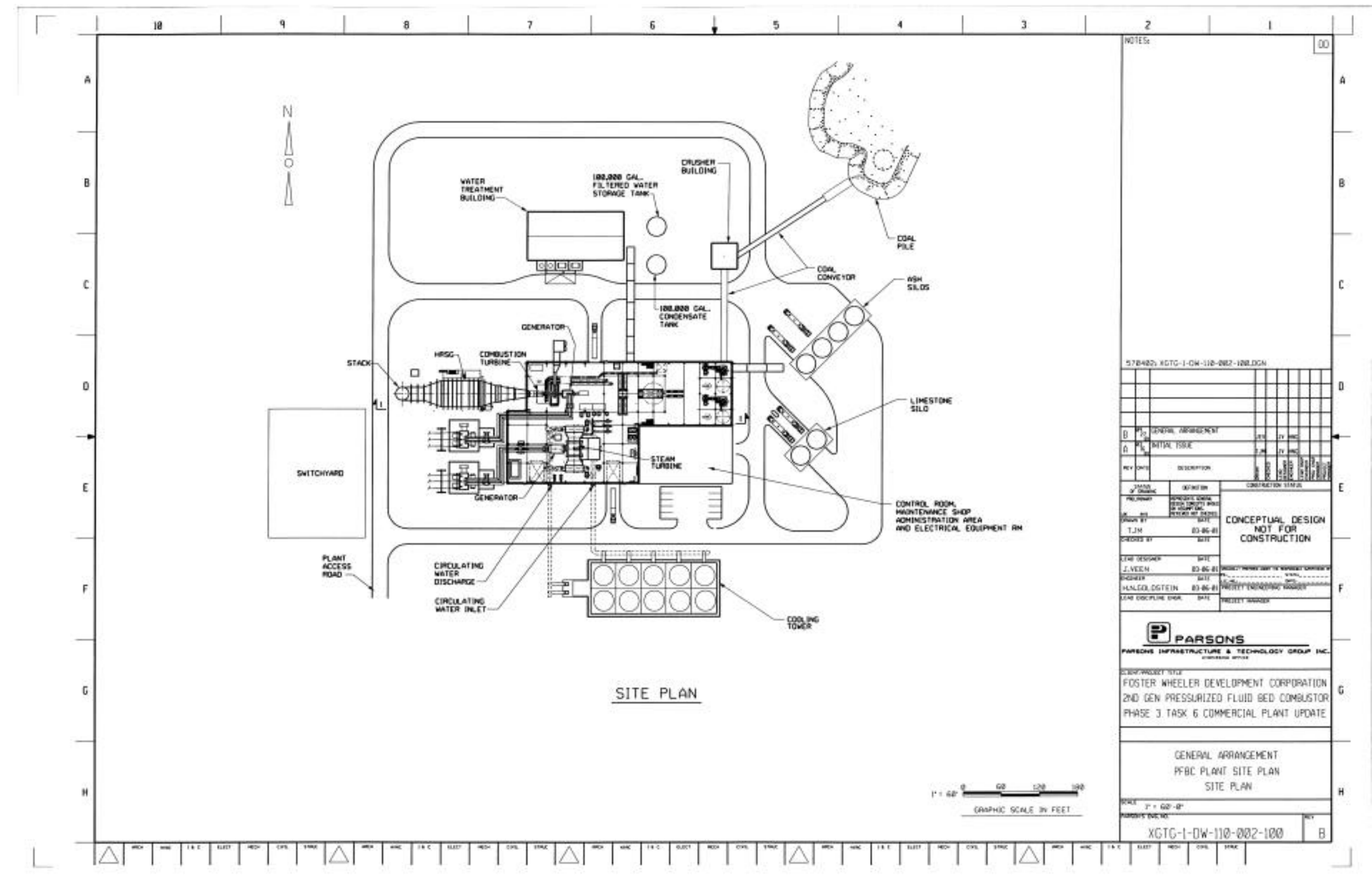

Fig. 21 Overall Site Plan 


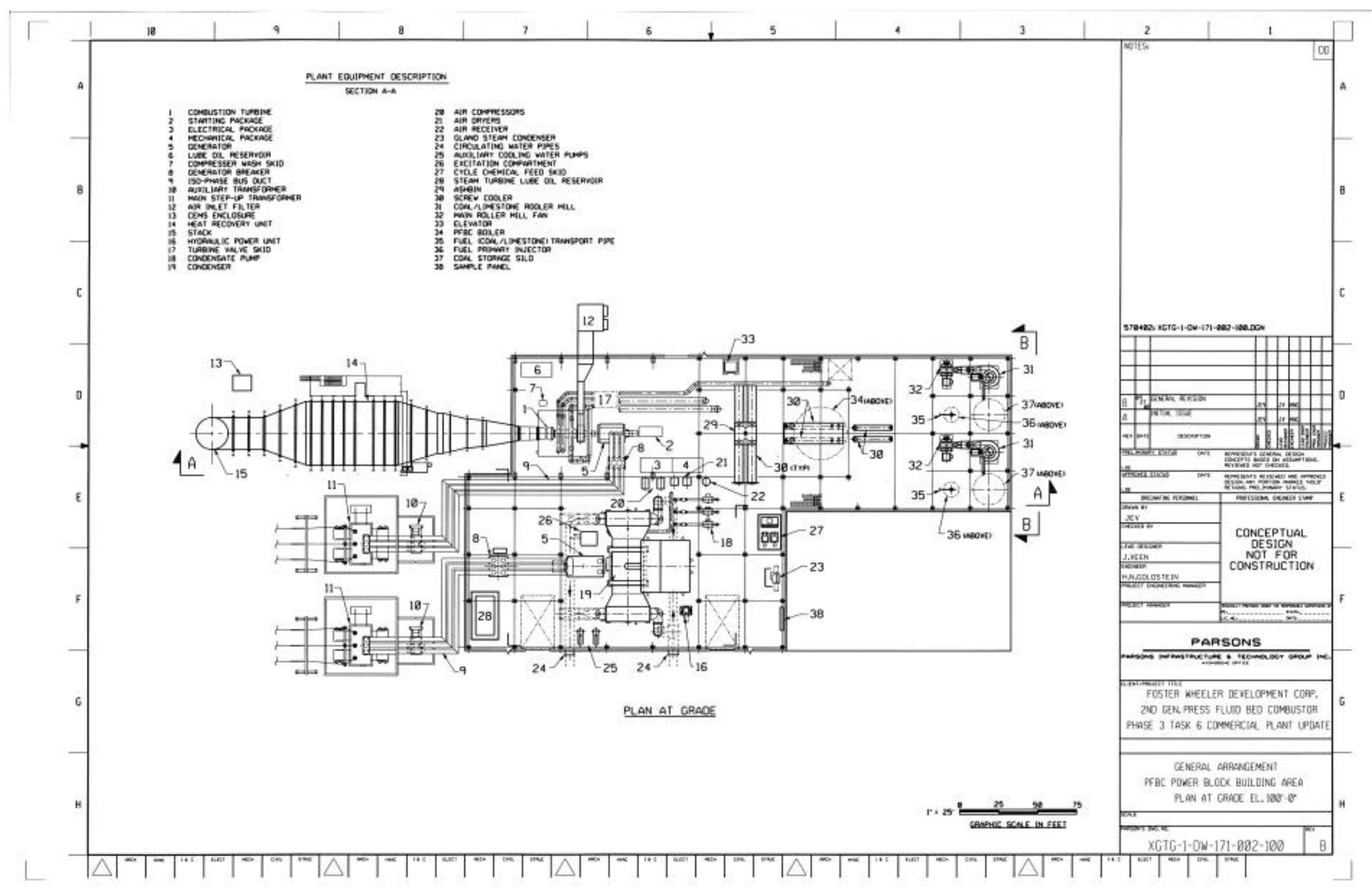

Fig. 22 Plan at Grade 


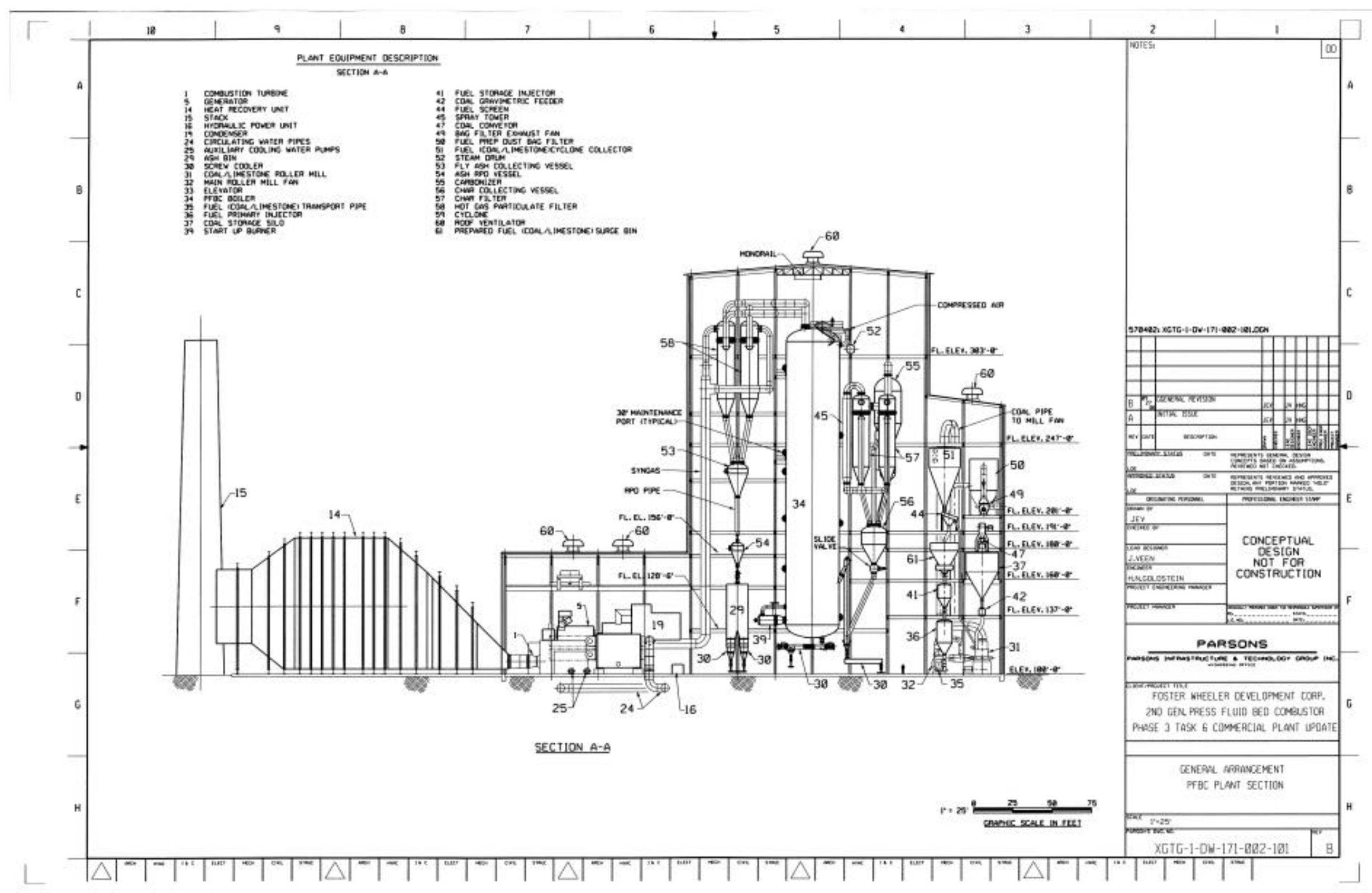

Fig. 23 Plant Elevation 


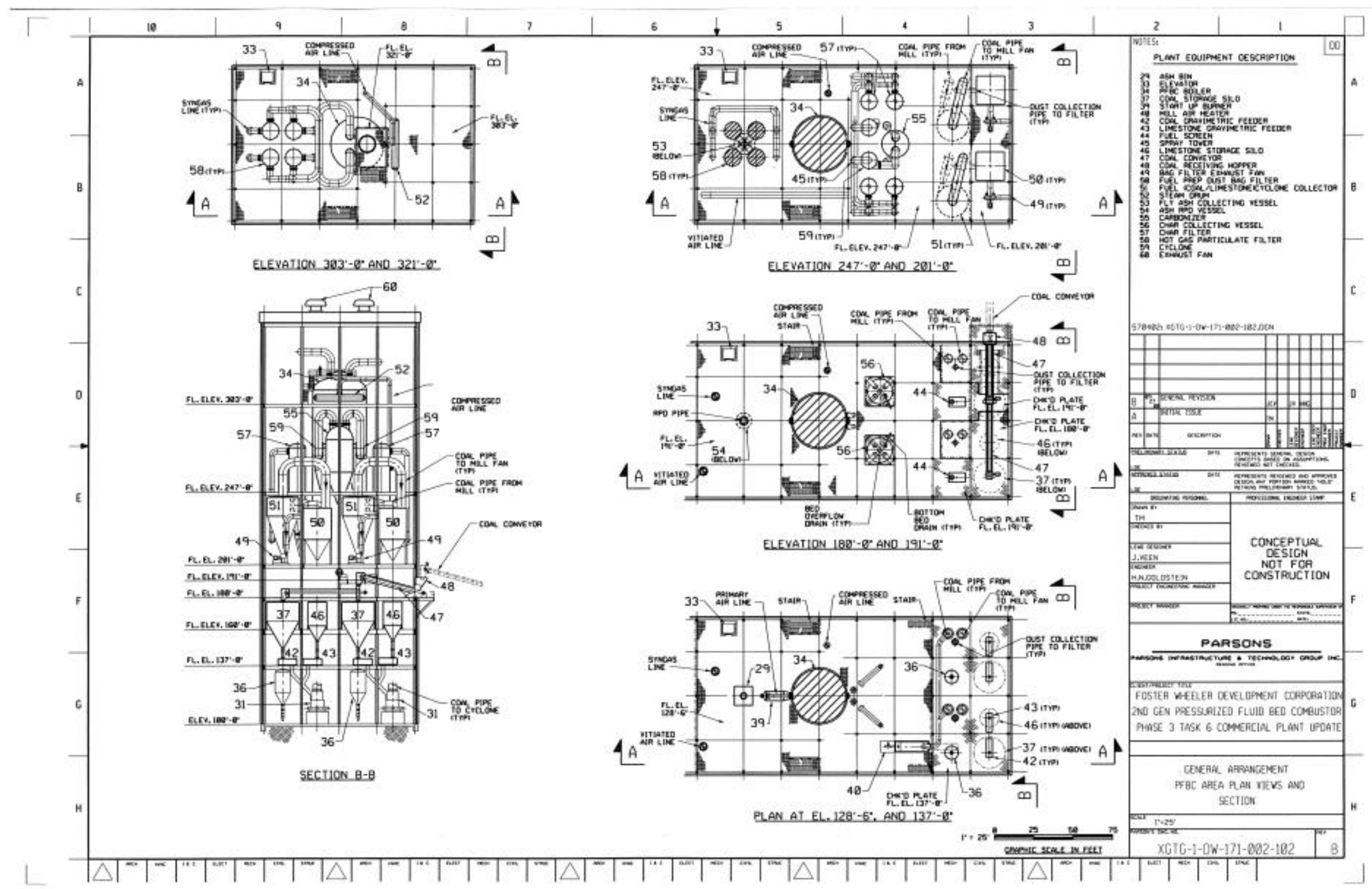

Fig. 24 Plant Sectional Views 


\subsection{Sensitivity Studies}

An analysis is being conducted to determine the sensitivity of plant performance and, in some cases, economics to different operating conditions or design assumptions. The starting point for the study is the updated baseline plant design. In each sensitivity case we have tried to change only one variable at a time to allow identification of its impact; the cases being studied are as follows:

1. baseline but with large field fabricated candle filter vessels rather than smaller railshipped units

2. baseline but with SCR installed to reduce NOx to $15 \mathrm{ppm}$ at $15 \% \mathrm{O}_{2}$

3. baseline but with stack gas $\mathrm{CO}_{2}$ removal

4. baseline but with alloy filters and alloy filter to gas turbine piping

5. baseline but with limestone rather than dolomite sorbent

6. baseline but designed for maximum power output

7. baseline but with upgraded turbines ("H" class rather than "G" class gas turbine and supercritical rather than subcritical pressure steam turbine)

From an economics standpoint only the first 5 cases will be cost estimated, and hence Cases 6 and 7 will be limited solely to identification of performance effects.

Plant heat and material balances have been completed for Cases 4 and 5 , and they are presented in Figs. 25 and 26 respectively. In Case 4 the limestone fed plant is designed to operate with the same calcium-to-sulfur molar feed ratio as that of the dolomite fed baseline. Since the calcium content of limestone is more than $50 \%$ higher than that of dolomite, Case 4 requires a much smaller sorbent flow rate. This results in a slight increase in plant efficiency, e.g., $48.1 \%$ versus $48.0 \%$ due reduced calcination heat loss, reduced ash flow, slightly reduced heat rejection, etc.

In Case 5 the syngas and PCFB vitiated air/flue gas are cooled to approximately $1000 \mathrm{EF}$ and $1200 \mathrm{EF}$ respectively by the use of convective heat exchangers that transfer that heat to the steam cycle. As a result of this cooling, the filters can use porous metal iron aluminide candles that are much more ductile/forgiving than silicon carbide candles. The filter to gas turbine piping can also be furnished in alloy steel thereby eliminating the need for high temperature valving and refractory lined piping with metallic liners.

Because the gas temperatures are reduced, the topping combustor requires additional syngas and additional oxygen containing vitiated air to maintain its firing temperature. To provide additional syngas and to reduce the char flow to the PCFB boiler so the vitiated air oxygen content can be increased, the carbonizer temperature is increased to $1800 \mathrm{EF}$. The reduced char flow generated by the carbonizer is cooled to $500 \mathrm{EF}$ by heat transfer to the steam cycle to similarly eliminate the need for high-temperature valving and refractory lined piping in the char feed lines to the PCFB boiler. The overall plant output reduces to $467.0 \mathrm{MWe}$ and the efficiency decreases to $45.8 \%$. 


\subsection{Conclusions}

The conceptual design of the baseline plant which incorporates a W 501G gas turbine together with a $2400 \mathrm{psig} / 1050 \mathrm{EF} / 1050 \mathrm{EF} 2-1 / 2$ " Hg steam turbine has been completed. Analyses show the plant will have an HHV efficiency of $48 \%$, which is three points higher than the $45 \%$ project goal. The costs of the baseline plant are being determined and will be compared to that of a conventional PC plant to confirm that the cost of electricity will be at least $20 \%$ lower than that of the latter, a second goal of the project.

\subsection{References}

6-1 Robertson, A., et.al. "Conceptual Design and Optimization of a Second Generation PFB Combustion Plant", Phase 1 Task 1 Topical Report, DOE/MC/21023-2825. Vol 1 (DE90000412), September 1989

\subsection{Bibliography}

Not applicable.

\subsection{Acronyms and Abbreviations}

$\begin{array}{ll}\text { Item } & \text { Description } \\ \text { APCFB } & \begin{array}{l}\text { advanced pressurized circulating fluidized bed } \\ \text { air boost compressor } \\ \text { BC }\end{array} \\ \text { BFW } & \text { boiler feed water } \\ \text { DOE } & \text { United States Department of Energy } \\ \text { F } & \text { fluidized bed heat exchanger } \\ \text { FBHE } & \text { Foster Wheeler } \\ \text { FW } & \text { gas turbine compressor } \\ \text { GC } & \text { gas turbine expander } \\ \text { GT } & \text { mercury } \\ \text { Hg } & \text { hot gas filter } \\ \text { HG } & \text { higher heating value } \\ \text { HHV } & \text { heat recovery unit } \\ \text { HRU } & \text { pulverized coal } \\ \text { PC } & \text { pressurized circulating fluidized bed } \\ \text { PCFB } & \text { Siemens Westinghouse Power Corporation } \\ \text { SW } & \text { compressed air bypass valve } \\ \text { Vab } & \text { compressed air supply valve } \\ \text { Vas } & \text { carbonizer syngas flare valve } \\ \text { Vcf } & \text { carbonizer air shut off valve } \\ \text { Vci } & \text { carbonizer gas control valve } \\ \text { Vco } & \text { natural gas fuel control valve } \\ \text { Vng } & \text { PCFB vitiated air flare valve } \\ \text { Vpf } & \text { PCFB air control valve } \\ \text { Vpi } & \text { PCFB vitiated air outlet valve } \\ \text { Vpo } & \\ & \end{array}$




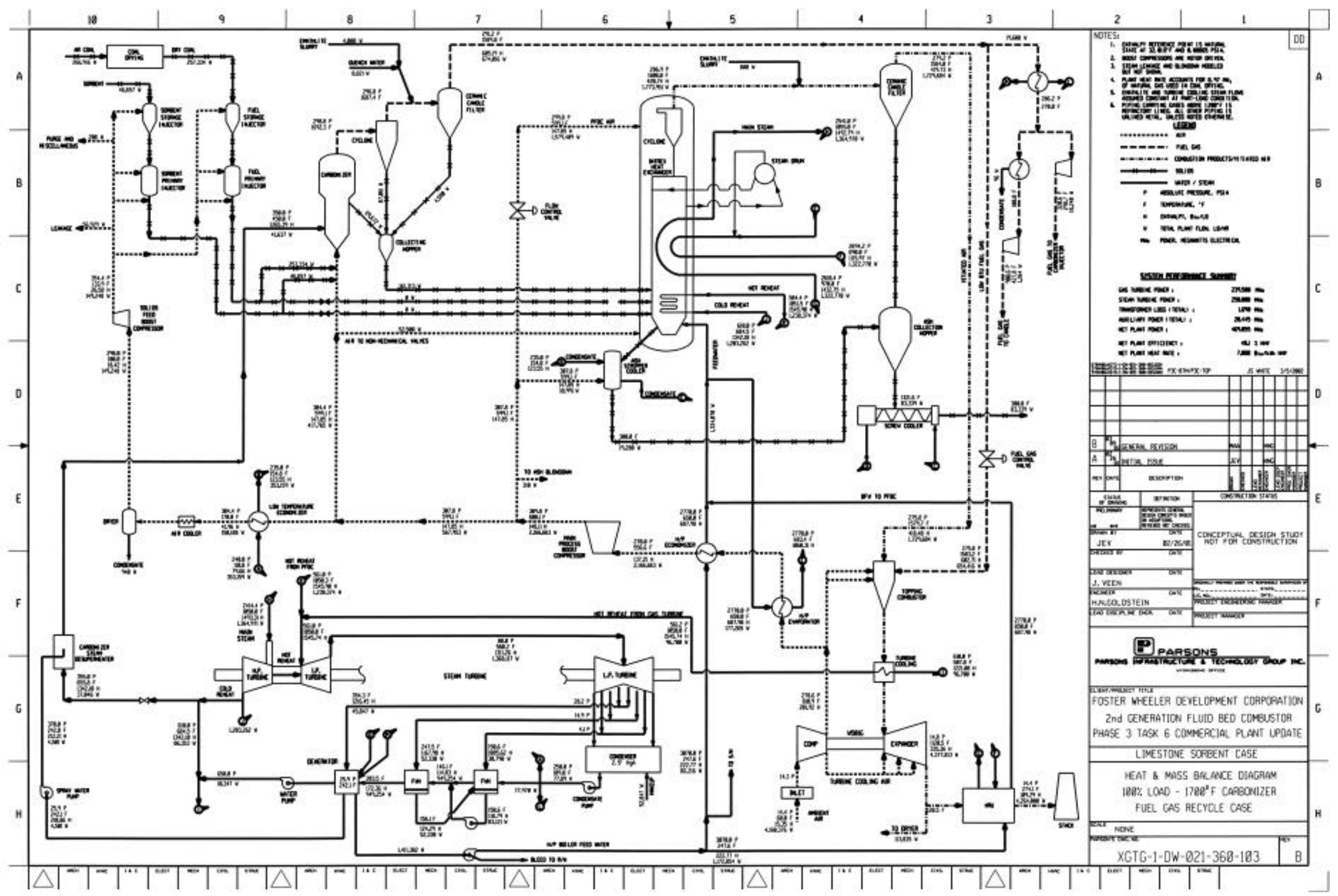

Fig. 25 Baseline Plant with Limestone Sorbent 


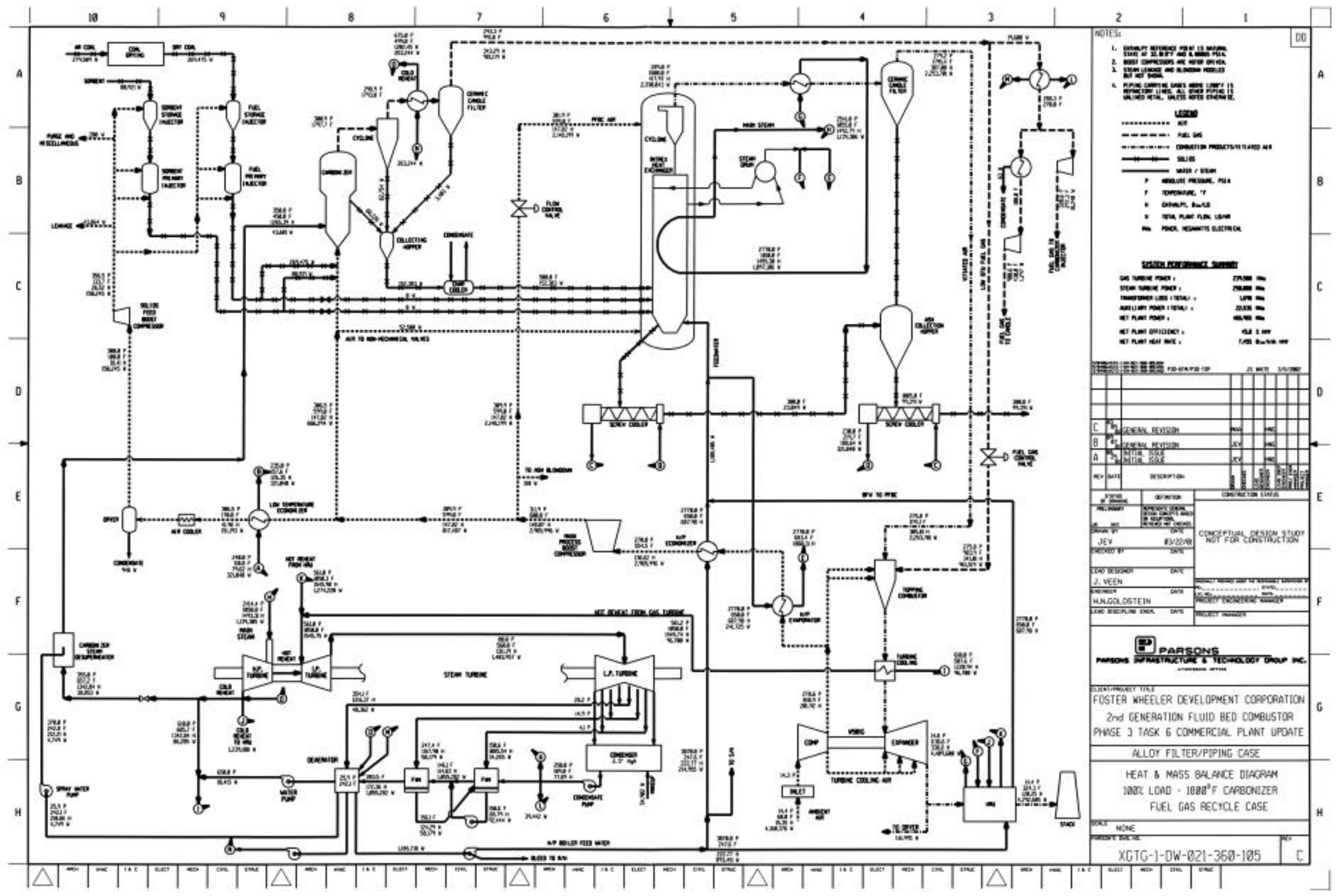

Fig. 26 Baseline Plant with Alloy Filter Piping 